NBS MONOGRAPH 26
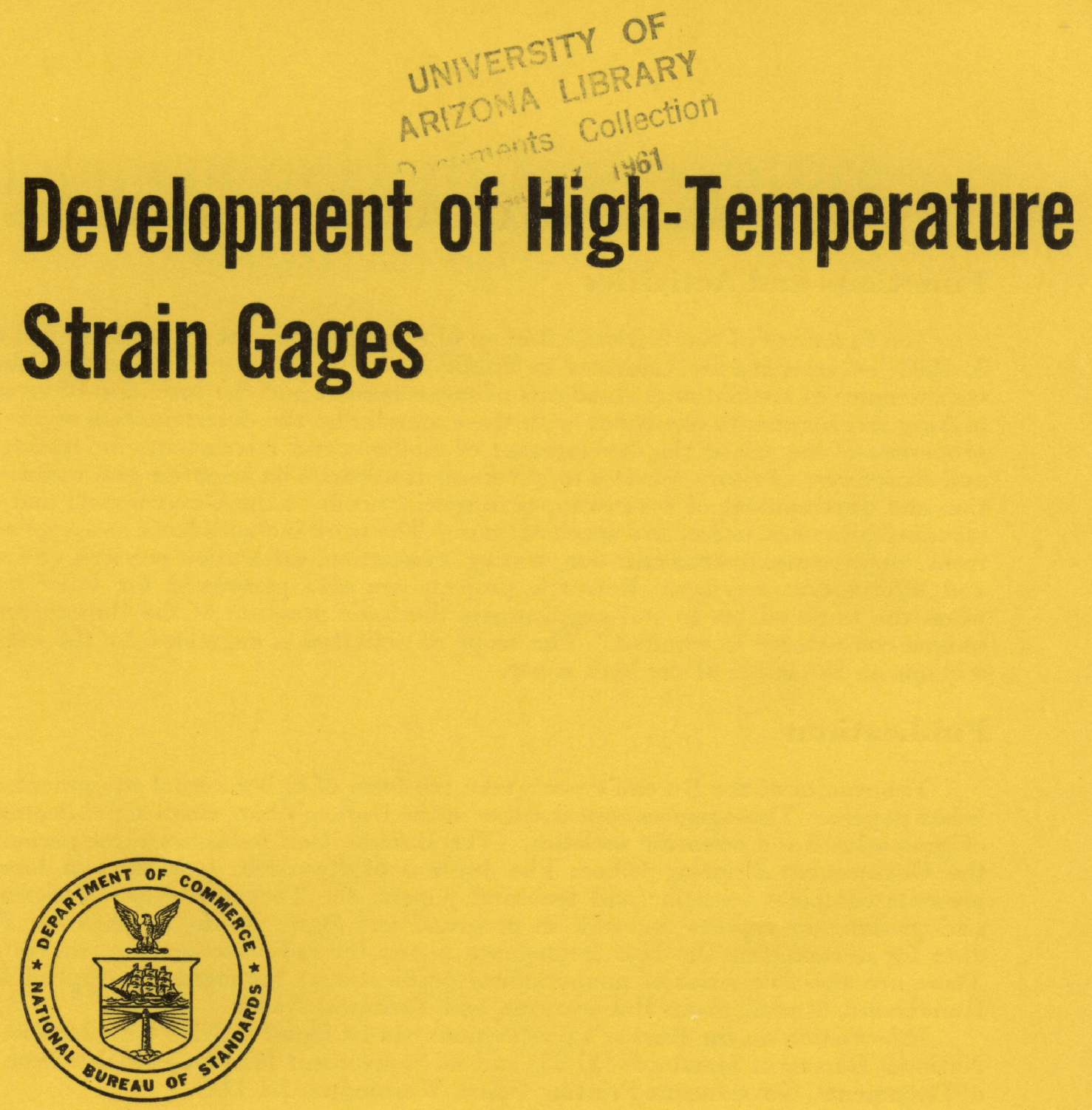

U.S. DEPARTMENT OF COMMERCE NATIONAL BUREAU OF STANDARDS 


\section{THE NATIONAL BUREAU OF STANDARDS}

\section{Functions and Activities}

The functions of the National Bureau of Standards are set forth in the Act of Congress, March 3, 1901, as amended by Congress in Public Law 619, 1950. These include the development and maintenance of the national standards of measurement and the provision of means and methods for making measurements consistent with these standards; the determination of physical constants; and properties of materials; the development of methods and instruments for testing materials, devices, and structures; advisory services to government agencies on scientific and technical problems; invention and development of devices to serve special needs of the Government; and the development of standard practices, codes, and specifications. The work includes basic and applied research, development, engineering, instrumentation, testing, evaluation, calibration services, and various consultation and information services. Research projects are also performed for other government agencies when the work relates to and supplements the basic program of the Bureau or when the Bureau's unique competence is required. The scope of activities is suggested by the listing of divisions and sections on the inside of the back cover.

\section{Publications}

The results of the Bureau's work take the form of either actual equipment and devices or published papers. These papers appear either in the Bureau's own series of publications or in the journals of professional and scientific societies. The Bureau itself publishes three periodicals available from the Government Printing Office: The Journal of Research, published in four separate sections, presents complete scientific and technical papers; the Tochnical News Bulletin presents summary and preliminary reports on work in progress; and Basic Radio Propagation Predictions provides data for determining the best frequencies to use for radio communications throughout the world. There are also five series of nonperiodical publications: Monographs, Applied Mathematics Series, Handbooks, Miscellaneous Publications, and Technical Notes.

Information on the Bureau's publications can be found in NBS Circular 460, Publications of the National Bureau of Standards (\$1.25) and its Supplement (\$1.50), available from the Superintendent of Documents, Government Printing Office, Washington 25, D.C. 
UNITED STATES DEPARTMENT OF COMMERCE • Luther H. Hodges, Secreary NATIONAL BUREAU OF STANDARDS - A. V. Astin, Director

\title{
Development of High-Temperature Strain Gages
}

\author{
J. W. Pitts and D. G. Moore
}

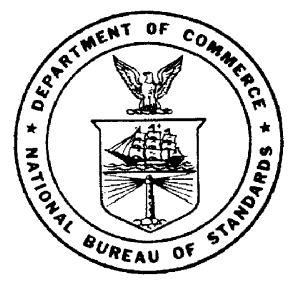

\section{National Bureau of Standards Monograph 26}

Issued March 17, 1961 



\section{Foreword}

Reliable data on the mechanical properties of structural materials at high temperatures are of critical importance in the development of aircraft engines, aircraft and missile frames subject to aerodynamic heating, and certain types of nuclear reactors. The measurement of strain in such structures not only provides the engineer with knowledge of the performance characteristics of the structure, but also gives information for improving the design.

This Monograph summarizes work done at the National Bureau of Standards in a research program aimed at the development of new types of strain gages for high-temperature use. Sponsored by the Navy and the Air Force, the program has included an investigation of the properties of high-temperature strain-gage materials, the development of high-temperature strain gages, and the development and evaluation of high-temperature strain-gage cements.

In discussing properties of strain-gage materials, it has been necessary to use proprietary names in referring to some of these materials. However, it should be understood that the Bureau does not recommend nor endorse any of the proprietary products mentioned in this Monograph.

A. V. Astin, Director. 


\section{Contents}

1. Introduction . . . . . . . . . . . . . .

2. Investigation of properties of high-temperature strain gage materials ........

2.1. Wires .............................

a. Temperature coefficient of resist-

b. Stress-strain relations. ..............

c. Gage factor......

d. Drift . . . . . . . . .

2.2. Ceramies

b. Effect of curing temperature on flexibility of cements

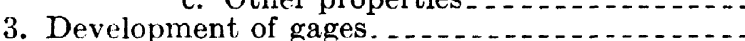

3.1. Metal-backed gages . . . . . . . . . . . .

3.2. Plastic-backed gage $\ldots \ldots \ldots$

3.3. Asbestos paper-backed gage .........

a. Design and fabrication...........

b. Characteristics........

(1) Gage factor .............

(2) Effect of cement thickness on gage factor.............

(3) Strain response at high strain levels.

(4) Behavior of gages attached to metals of different thermal expansivities .............
3. Development of gages-Continued

3.3 Asbestos paper-backed gage-Continued

b. Characteristics-Continued

(5) Resistance to ground....... 10

(6) Effect of surface roughness on gage response.......... 10

(7) Effect of thermal cycling on gage behavior.

3.4. Unbacked wire-grid gages _............ 10

a. Design and fabrication ........... 11

b. Ceramic-coated gage............ 11

c. Characteristics................. 11

4. Development and evaluation of high-temperature strain gage cements................ 12

4.1. Resistivity _.................... 12

4.2. Strength $\ldots \ldots \ldots \ldots$

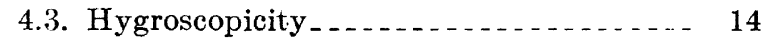

4.4. Minimum curing temperature ......... 14

a. Stability of cements on slow and rapid heating to $600^{\circ} \mathrm{F} \ldots \ldots \ldots 15$

b. Theory of cement instability ..... 16

c. Relation of minimum curing temperature to operation of gages . ... - 18

5. Concluding remarks..................... 19

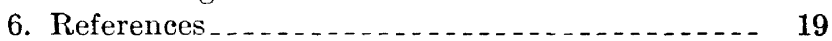

T 


\title{
Development of High-Temperature Strain Gages
}

\author{
J. W. Pitts and D. G. Moore
}

\begin{abstract}
A summary is presented of a research program aimed at the improvement of hightemperature strain gages of the electrical resistance type. Potential ceramic and metal components were evaluated and a gage was devised that was based on these evaluations. This gage (NBS 5B) was flexible and easy to install; however, it lacked resistance stability at higher temperatures. In an attempt to minimize this deficiency, ceramic cements were developed that showed greater electrical resistivity than had been previously observed in the range 800 to $1,800{ }^{\circ} \mathrm{F}$; also, a technique was devised for increasing the resistance to ground by applying a fired-on ceramic coating to the grid of a specially developed unbacked gage.

A study was made of the cause of the erratic response of cemented gages that had not been preheated prior to use. There were strong indications that the erratic response was caused mostly by the rapid decrease in resistance that accompanied structural changes in the cement.
\end{abstract}

\section{Introduction}

The period since World War II has seen a greatly expanded use of electrical resistance strain gages for the determination of strains in aircraft structures. The gages that are most often used for this purpose consist of an alloy wire filament on a paper or resin backing that can be bonded to the test structure by means of an organic adhesive. These gages give good performance at or near room temperature, but unfortunately the maximum temperature at which they will operate satisfactorily is about $350{ }^{\circ} \mathrm{F}$ [1]. ${ }^{2}$ Above this temperature, both the backing and the adhesive deteriorate and the full amount of strain is not transmitted to the filament wire. It is obvious that such gages cannot be used to measure strains at high temperatures such as, for example, in aircraft engines, or in aircraft and missile structures that are exposed to severe aerodynamic heating.

A logical approach towards extending the upper temperature limit of a resistance-type gage is to substitute a ceramic cement for the organic resin. The development of such a gage was first reported by Schabtach and Fehr [2] in 1944 and later by Kemp, Morgan, and Mansion in 1947 [3]. Gages of this type were used successfully to measure dynamic strains at temperatures as high as $1,500^{\circ} \mathrm{F}$ and, by 1954, several designs of ceramic-bonded gages were in various stages of development in a number of laboratories [4]. However, none of these was completely satisfactory for static strain measurements; in addition, each of the designs required a considerable amount of skill on the part of the operator to prepare and mount the gage on the test structure. An improved high-temperature gage was needed, and in an attempt to fill this need an investigation was initiated in February 1954 in the Enameled Metals Laboratory at the National Bureau of Standards. The present Monograph constitutes a final summary report on this program.

\section{Investigation of Properties of High-Temperature Strain Gage Materials}

\subsection{Wires}

The ideal strain gage wire should have the following properties: (1) Oxidation resistance over the useful temperature range, (2) high electrical resistivity (3) zero temperature coefficient of resistance over the useful range, (4) high and constant gage factor, and (5) metallurgical stability.

No single alloy wire is known to have all of these properties; therefore, the selection of a particular wire depends on its having certain desirable prop-

1 The work described in this Monograph was sponsored by the Burean of Aeronautics, Department of the Navy, Wright Air Development Center, Department of the Air Force, and partially by the Bureau of Ships, Department of the Nary.

2 Figures in brackets indicate the literature references at the end of this Monograph. erties relevant to a particular application; or, more frequently, the exclusion of a wire is based on its having an intolerable deficiency. The names of some of the alloy wires that have been considered for high-temperature strain gage use, their compositions and their published characteristics are given in table 1. Certain properties of wires that were investigated in this program are discussed in the following sections.

\section{a. Temperature Coefficient of Resistance}

Figure 1 shows the resistance changes with temperature as determined for 1-mil diameter wires of cold-drawn Nichrome V, heat-treated Karma, and cold-drawn $80 \mathrm{Pt-20}$ Ir alloy, all heated in air 
TABLE 1. Compositions and properties of some fine wires which have been used or considered for use in high-temperature strain gages ${ }^{\text {a }}$

\begin{tabular}{|c|c|c|c|c|c|c|c|}
\hline \multirow[t]{2}{*}{ Metal or alloy } & \multirow{2}{*}{ Nominal composition } & \multirow{2}{*}{$\begin{array}{c}\begin{array}{c}\text { Resistivity } \\
\text { at room } \\
\text { temper- } \\
\text { ature }\end{array} \\
\text { ohms per } \\
\text { cir mil-ft }\end{array}$} & \multicolumn{2}{|c|}{$\begin{array}{l}\text { Mean temperature } \\
\text { coefficient of resistivity }\end{array}$} & \multicolumn{2}{|c|}{$\begin{array}{l}\text { Mean coefficient of linear } \\
\text { thermal expansion }\end{array}$} & \multirow{2}{*}{$\begin{array}{l}\text { Gage } \\
\text { factor at } \\
\text { room tem. } \\
\text { perature }\end{array}$} \\
\hline & & & ppm per ${ }^{\circ} \mathrm{F}$ & te $m p$ range, ${ }^{\circ} \mathrm{F}$ & $p p m p e r{ }^{\circ} F$ & temp range, ${ }^{\circ} \mathrm{F}$ & \\
\hline $\begin{array}{l}\text { Advance b... } \\
\text { Constant an } \\
\text { Copel } c_{\text {. }} \\
\text { Cuprond... }\end{array}$ & $\begin{array}{l}55 \mathrm{Cu}, 45 \mathrm{Ni} \\
55 \mathrm{Cu}, 45 \mathrm{Ni} \\
55 \mathrm{Cu}, 45 \mathrm{Ni} \\
55 \mathrm{Cu}, 45 \mathrm{Ni}\end{array}$ & $\begin{array}{l}294 \\
294 \\
294 \\
294\end{array}$ & $\begin{array}{l} \pm 10 \\
\pm 10 \\
\pm 10 \\
\pm 10\end{array}$ & $\begin{array}{l}68 \text { to } 212 \\
68 \text { to } 212 \\
68 \text { to } 212 \\
68 \text { to } 212\end{array}$ & $\begin{array}{l}8.3 \\
8.3 \\
8.3 \\
8.3\end{array}$ & $\begin{array}{l}68 \text { to } 212 \\
68 \text { to } 212 \\
68 \text { to } 212 \\
68 \text { to } 212\end{array}$ & $\begin{array}{l}2.1 \\
2.1 \\
2.2 \\
2.1\end{array}$ \\
\hline $\begin{array}{l}\text { Nichromeb } \\
\text { Tophet } \mathrm{C} d \mathrm{~A}\end{array}$ & $\begin{array}{l}61 \mathrm{Ni}, 24 \mathrm{Fe}, 15 \mathrm{Cr} \\
61 \mathrm{Ni}, 24 \mathrm{Fe}, 15 \mathrm{Cr}\end{array}$ & $\begin{array}{l}675 \\
675\end{array}$ & $\begin{array}{l}80 \\
70\end{array}$ & $\begin{array}{l}68 \text { to } 930 \\
32 \text { to } 212\end{array}$ & $\begin{array}{l}9.5 \\
7.5\end{array}$ & $\begin{array}{l}68 \text { to } 1830 \\
68 \text { to } 212\end{array}$ & $\begin{array}{l}2.7 \\
2.7\end{array}$ \\
\hline $\begin{array}{l}\text { Nichrome V b } \\
\text { Tophet } A^{d}\end{array}$ & $\begin{array}{l}80 \mathrm{Ni}, 20 \mathrm{Cr} \\
80 \mathrm{Ni}, 20 \mathrm{Cr}\end{array}$ & $\begin{array}{l}650 \\
650\end{array}$ & $\begin{array}{l}60 \\
60\end{array}$ & $\begin{array}{l}68 \text { to } 930 \\
32 \text { to } 212\end{array}$ & $\begin{array}{l}9.5 \\
7.3\end{array}$ & $\begin{array}{l}68 \text { to } 1830 \\
68 \text { to } 212\end{array}$ & $\begin{array}{l}2.0 \\
2.3\end{array}$ \\
\hline $\begin{array}{l}\text { Evanohm d } \\
\text { Kárma b }\end{array}$ & $\begin{array}{l}74 \mathrm{Ni}, 20 \mathrm{Cr}, 3 \mathrm{Al}, 3 \mathrm{Cu} \\
74 \mathrm{Ni}, 20 \mathrm{Cr}, 3 \mathrm{Al}, 3 \mathrm{Fe}\end{array}$ & $\begin{array}{l}800 \\
800\end{array}$ & $\begin{array}{l} \pm 10 \\
\pm 10\end{array}$ & $\begin{array}{l}32 \text { to } 212 \\
32 \text { to } 212\end{array}$ & $\begin{array}{l}7.8 \\
7.4\end{array}$ & $\begin{array}{l}68 \text { to } 212 \\
68 \text { to } 212\end{array}$ & 2.0 \\
\hline Alloy $\mathrm{D} \cdot \ldots$ & $70 \mathrm{Fe}, 20 \mathrm{Cr}, 10 \mathrm{Al}$ & 1060 & -60 & 68 to 1830 & 9.1 & 68 to 1830 & 2.2 \\
\hline Alchromed.............. & $79 \mathrm{Fe}, 16 \mathrm{Cr}, 5 \mathrm{Al}$ & 820 & 10 & 32 to 212 & 7.5 & 68 to 212 & - \\
\hline $\begin{array}{l}\text { Platinum } \\
\text { Pt-Iridium } \\
\text { Pt-Iridium }\end{array}$ & $\begin{array}{l}100 \mathrm{Pt} \\
80 \mathrm{Pt}, 10 \mathrm{Ir} \\
80 \mathrm{Ir}\end{array}$ & $\begin{array}{r}64 \\
150 \\
200\end{array}$ & $\begin{array}{r}2170 \\
720 \\
440\end{array}$ & $\begin{array}{l}32 \text { to } 212 \\
32 \text { to } 212 \\
32 \text { to } 212\end{array}$ & $\begin{array}{r}4.9 \\
5.0 \\
-\end{array}$ & $\begin{array}{l}68 \text { to } 212 \\
68 \text { to } 212\end{array}$ & $\begin{array}{l}4.8 \\
5.3 \\
6.0\end{array}$ \\
\hline
\end{tabular}

a Sources of data: Manufacturers' literature and references [5], [15], [17], and [18]. These data are approximate inasmuch as most of the characteristics will vary with minor changes in composition and, particularly, with both the thermal and mechanical histories of the wires.

b. e. d Reristered trade names of the manufacturers, respectively: Driver-

at a rate of $10^{\circ} \mathrm{F}$ per minute. These results are in fair agreement with those reported by Kemp, Morgan, and Manson [5].

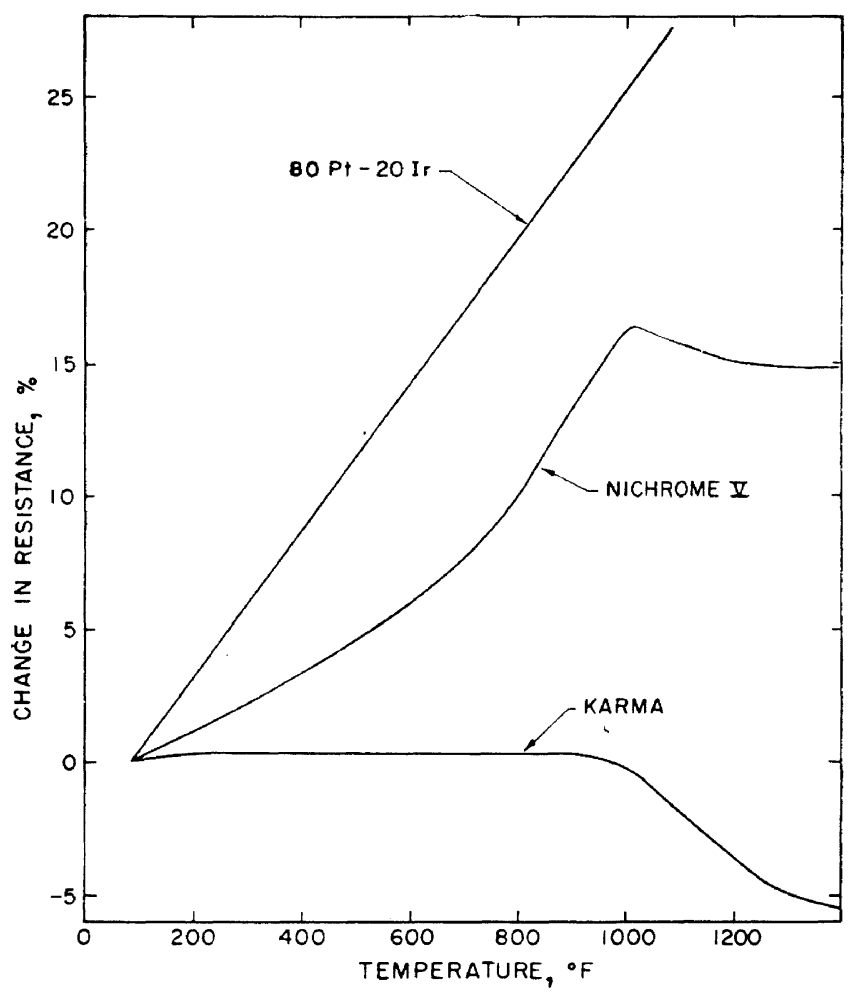

FIGURE 1. Resistance-temperature curves for three 1-mil diameter alloy wires.

Data for the curves were obtained during the first heating at a heating rate of approximately $10^{\circ} \mathrm{F}$ per minute.
IIarris Co., Harrison, N.J.; Hoskins Mfg. Co., Detroit, Mich.; and Wilbur 3. Driver Co., Newark, N.J

(Illinois Institute of Technology, Chicago, Ill.

\section{b. Stress-Strain Relations}

Because the mechanical properties of very fine wires are usually different from those of the bulk material, the room temperature stress-strain relations of three different 1-mil strain gage wires were determined. The wires were stressed in tension by dead-weight loading and the length changes were measured with a cathetometer. Figure 2 shows the stress-strain curves for colddrawn Nichrome V, heat-treated Karma, and colddrawn constantan. The observed 0.2 percent offset yield strength value of 79,000 psi for colddrawn constantan compares with a reported value of 50,000 psi for normal tensile-test bars of the material [6]. Also, the 0.2 percent offset yield strength of the cold-drawn Nichrome $V$ was found to be $240,000 \mathrm{psi}$, which is higher than the reported tensile strength value of $190,000 \mathrm{psi}$ for the cold-drawn bulk material. If it is assumed that the elastic limit is approximately the same as the proportional limit, then Nichrome V, Karma, and constantan can be used at room temperature to measure strains of about $6,000,2,700$, and 2,400 $\mu$ in./in. respectively, without plastic deformation of the 1-mil filaments.

\section{c. Gage Factor}

The gage factor of a wire is defined as the ratio of its percentage change in resistance to its percentage change in length.

The gage factor of Karma wire was determined at room temperature. The method consisted of spot welding 2 -in. lengths of 1-mil wire to strips of Inconel foil, then simultaneously measuring resistance changes and length changes while the 


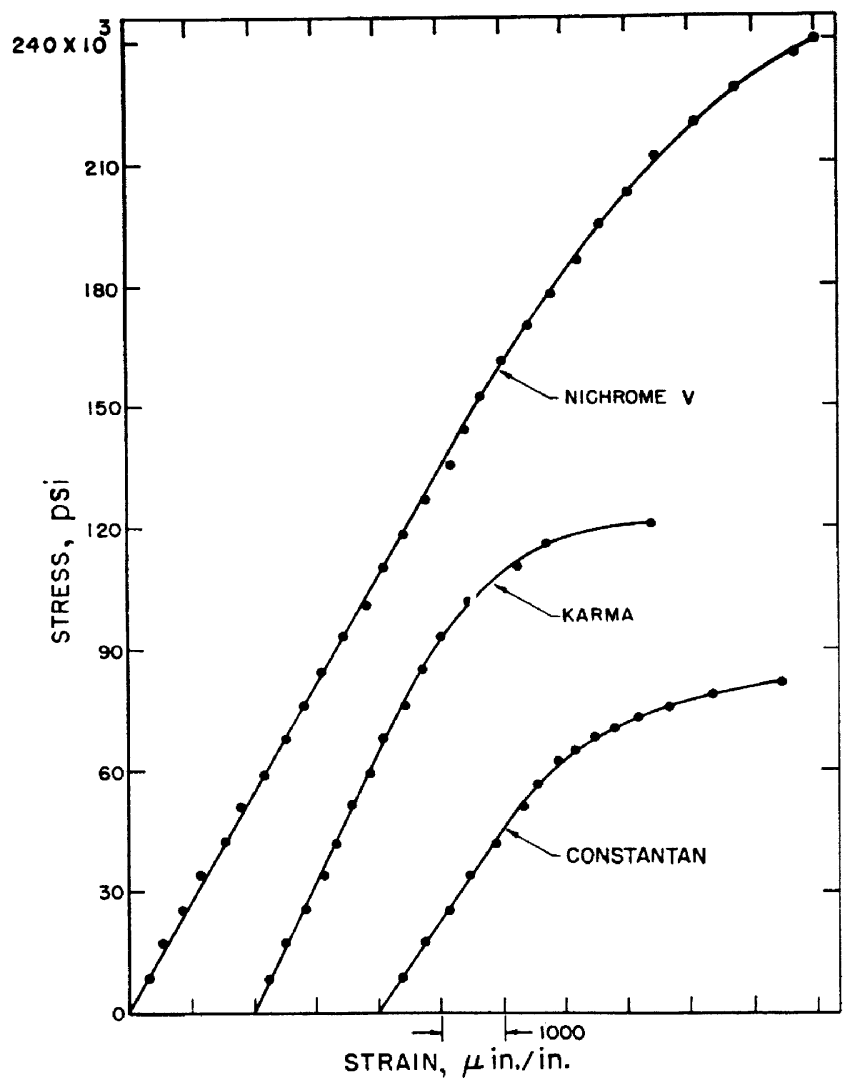

FIGURE 2. Room temperature stress-strain curves for 1-mil diameter strain gage flament wires.

wire was being stretched in tension. The average gage factor of 35 specimens was 2.22 with a standard deviation of 0.22 . This average is unaccountably lower than the 2.59 obtained for Karma wire strain gages (see section $3.3 \mathrm{~b}(1)$ ).

\section{d. Drift}

In making static strain measurements, it is important that the strain gage response remain stable under constant temperature and stress conditions. There are a number of possible causes for gage drift, some of which are associated with the wire only. For instance, a reduction in crosssectional area by oxidation can cause a wire to increase in resistance ${ }^{3}$; also, its resistance can change at constant elevated temperature either by metallurgical transformations or by relief of residual stresses. In order to determine the extent of these effects, a number of measurements were made of the resistance changes occurring in unstressed, bare wires heated in air. Figure 3 shows the change in resistance after one hour of heating at a series of temperatures for 1-mil wires of $\mathrm{Ni}$ chrome V, Karma, and 80 Pt-20 Ir alloy. Although these results do not distinguish between the various contributing factors, it is probable that structural changes are predominant at the lower

$3 \mathrm{Kemp}$ [7] has calculated that a 1-mil diam wire with a gagn factor of 2.0 would change $100 \mu \mathrm{in}$./in. in indicated strain if a surface layer of metal only $5 \times 10^{-8}$ in. thick were removed.

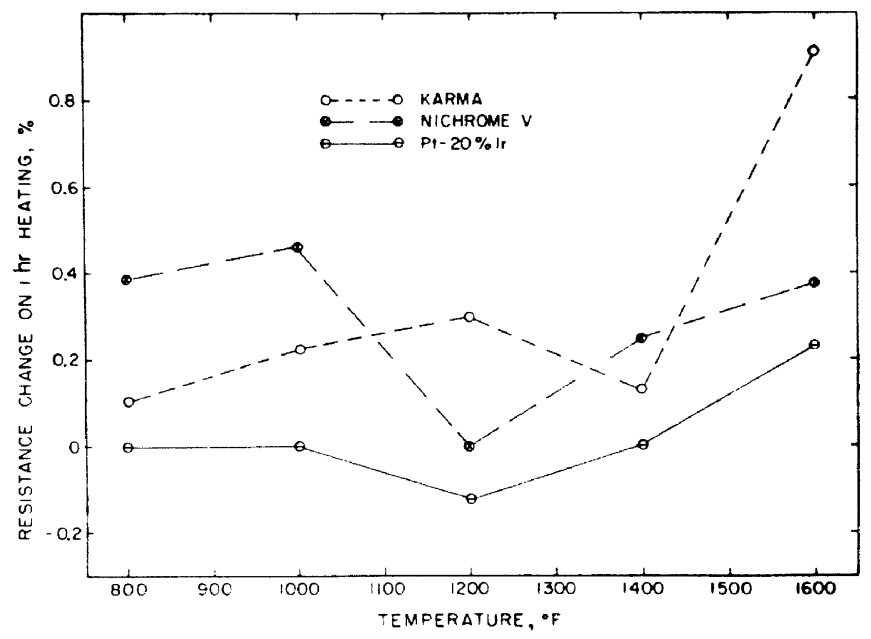

FIGURE 3. Change in elevated temperature resistance after one hour of heating plotted against temperature for unprotected 1-mil diameter wires.

The Karma and $80 \mathrm{Pt}-20 \mathrm{Ir}$ alloy were heated to $1,600^{\circ} \mathrm{F}$ and furnace cooled prior to testing while the Nichrome $V$ wire was heated to $1,000^{\circ} \mathrm{F}$ and air quenched. (No measurements were made below $800^{\circ} \mathrm{F}$ ).

temperatures while oxidation and/or gas diffusion contribute to resistance increases at the higher temperatures.

Although Karma wire was found to have a comparatively low-drift rate in the temperature range of 75 to $800^{\circ} \mathrm{F}$, it was believed possible to reduce it further. In all previous extended heating tests of wires it had been noted that drift rates decreased with time at a given temperature. Therefore, it seemed likely that if the wires were pretreated at or above the anticipated test temperatures for prolonged periods, then the resistances would eventually become stabilized.

A series of Karma wire specimens were heat treated at temperatures varying from 800 to 1,800 ${ }^{\circ} \mathrm{F}$ and for times varying from 1 to $24 \mathrm{hr}$. After this stabilizing treatment, drift measurements were made for a 5 -hr period at temperatures of 400,600 , and $800^{\circ} \mathrm{F}$.

It was found that preheating at $1,200{ }^{\circ} \mathrm{F}$ and above not only increased subsequent drift rates but was detrimental to both the high-resistance and the low-temperature coefficients of resistance, which were originally induced in the wire by the manufacturer's heat treatment. However, heat treating at either 800 or $1,000^{\circ} \mathrm{F}$ was effective in reducing drift, as indicated in the table below:

\begin{tabular}{|c|c|c|c|}
\hline \multirow{2}{*}{$\begin{array}{l}\text { Stabilizing } \\
\text { heat treatment }\end{array}$} & \multicolumn{3}{|c|}{$\begin{array}{c}\text { Percent increase in resist- } \\
\text { ance after } 5 \text { hr additional } \\
\text { heating at: }\end{array}$} \\
\hline & $400^{\circ} \mathrm{F}$ & $600^{\circ} \mathrm{F}$ & $800^{\circ} \mathrm{F}$ \\
\hline $\begin{array}{l}\text { None } \\
24 \mathrm{hr} \text { at } 1,000^{\circ} \mathrm{F}- \\
24 \mathrm{hr} \text { at } 800^{\circ} \mathrm{F}\end{array}$ & $\begin{array}{l}0.06 \\
0 \\
0\end{array}$ & $\begin{array}{l}0.04 \\
0 \\
0\end{array}$ & $\begin{array}{r}0.72 \\
.73 \\
.16\end{array}$ \\
\hline
\end{tabular}


As a result of these findings, Karma wire was heat treated for at least $24 \mathrm{hr}$ at $800{ }^{\circ} \mathrm{F}$ prior to use in strain gages.

\subsection{Ceramics}

\section{a. Corrosiveness of Gements}

The effect of ceramic cements on the resistances of fine wires was determined by embedding Nichrome V wires in various cements, heating the specimens to selected temperatures, and then measuring the resistance changes of the wires at constant temperature. Specimens were heated for $1 \mathrm{hr}$ at $800^{\circ} \mathrm{F}$, then for $1 \mathrm{hr}$ at each $200^{\circ} \mathrm{F}$ interval to $1,600^{\circ} \mathrm{F}$. The results for the 1,400 ${ }^{\circ} \mathrm{F}$ heating are shown in figure 4 . These curves show that some ceramic cements have very corrosive effects on wires, while others are protective. As pointed out earlier by Moore [8] the experimental cements showing corrosive attack ( $\mathrm{S}-1$, $\mathrm{S}-7, \mathrm{~S}-19$, and $\mathrm{N}-1$ ) all contain sodium silicate as a bonding agent. $\mathrm{C}-1$ and $\mathrm{C}-3$ are commercial cements.

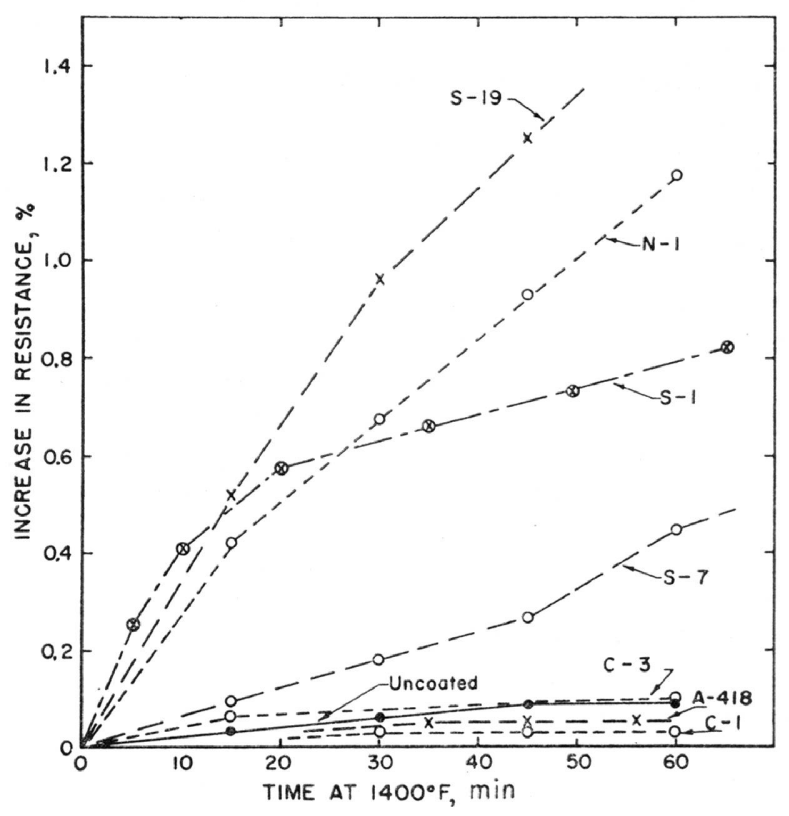

Figure 4. Change in resistance with time at $1,400^{\circ} \mathrm{F}$ for Nichrome $V$ wires: one uncoated, one coated with A-418 fused-on ceramic coating, and six embedded in six different air-drying cements $(C-1, C-3, S-1, S-7, S-19$, and $N-1)$.

Because of the inertness displayed by cement $\mathrm{C}-1$ in these tests and also because of its other desirable properties, it was used almost exclusively throughout the earlier parts of this investigation tor attaching gages. This cement is a phosphate-bonded type containing quartz and other oxides as fillers.

Corrosion of the base alloy by the wet cement can also be a serious problem. Figure 5 shows
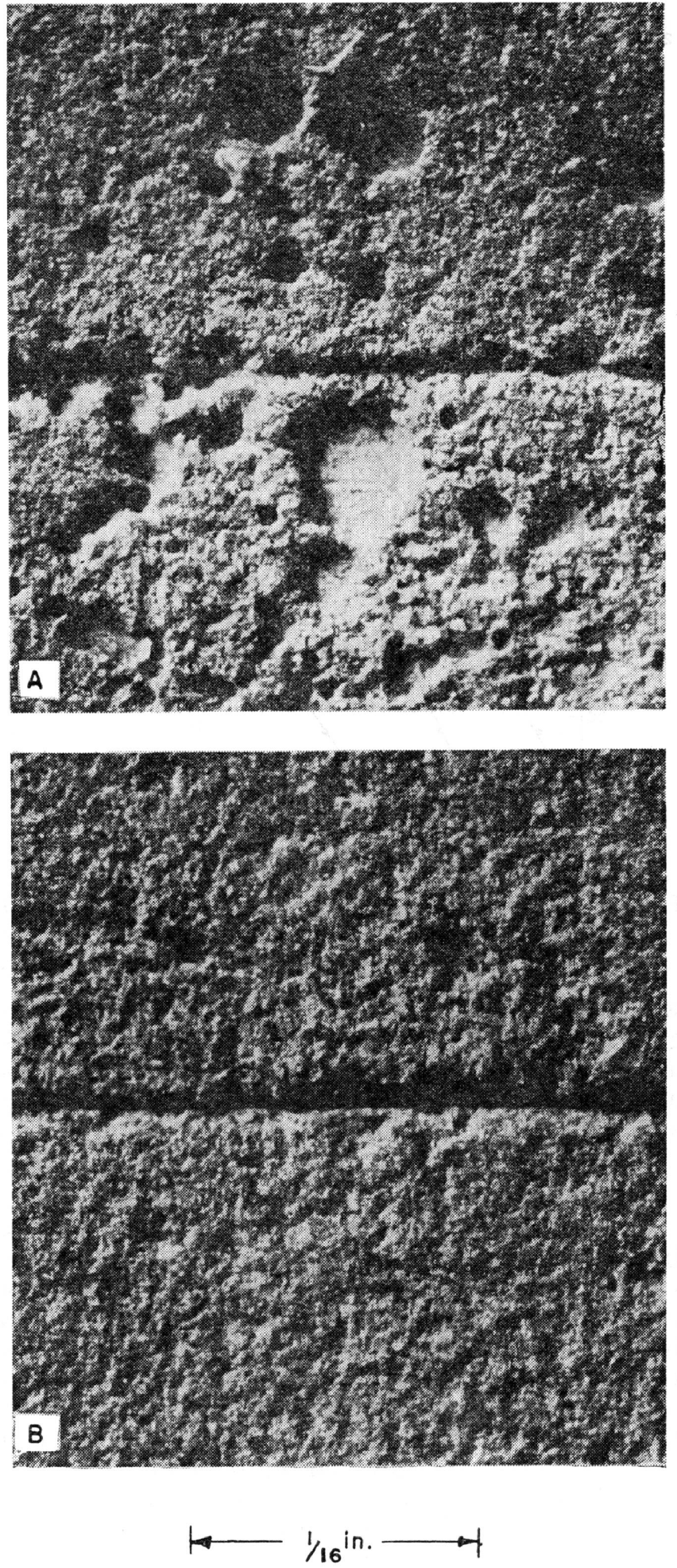

FIGURE 5. Photomicrographs showing the effects of the corrosion which occurred when strain gages were cemented to specimens of aluminum alloy 2024 .

The photos were taken normal to the plane of the cement after the top layers of cement had been scraped away and after the strain gage wires had been removed (leaving the troughs which appear as dark horizontal bands).

what can happen when a strain gage is attached with a cement displaying strong acidic reaction. The specimens photographed in figure 5 were 
prepared by cementing wire gages to aluminum alloy 2024 with two different cements. After drying and curing at $600{ }^{\circ} \mathrm{F}$, the cements were scraped away until the wires were exposed and could be removed. The cement in figure $5 \mathrm{~A}$ has a $p \mathrm{H}$ of about 0.2 and vigorous reaction with the aluminum alloy is presumed to have occurred as evidenced by the gas pockets throughout the structure. This same cement on a corrosionresistant base showed no such effect. The cement used for the specimen in figure 5B was less reactive toward the aluminum alloy. The $p \mathrm{H}$ of the bonding agent used in this second cement is 2.0 ; also, this cement contains an acid inhibitor.

\section{b. Effect of Curing Temperature on Flexibility of Cements}

The anticipated use oi a phosphate-bonded cement in the construction of a flexible ceramictype gage led to a study of the effect of curing temperature on the subsequent flexibility of a film of the cement at room temperature.

A modified bend test was devised for the experiments. Ingot iron specimens, 2.5 in. long by 0.5 in. wide by 0.043 in. thick were coated on one side with a 2 -mil layer of the $\mathrm{C}-1$ cement. Five specimens were cured at each of four selected temperatures and after cooling to room temperature the specimens were bent slightly in the long direction, so that the cement layer was on the convex side of the bend. The specimens were placed longitudinally in a compression machine and the bending continued until a crack appeared in the cement layer. The radius of curvature of each specimen was determined and the average radius of each group of five specimens was plotted as a function of temperature. Figure 6 shows

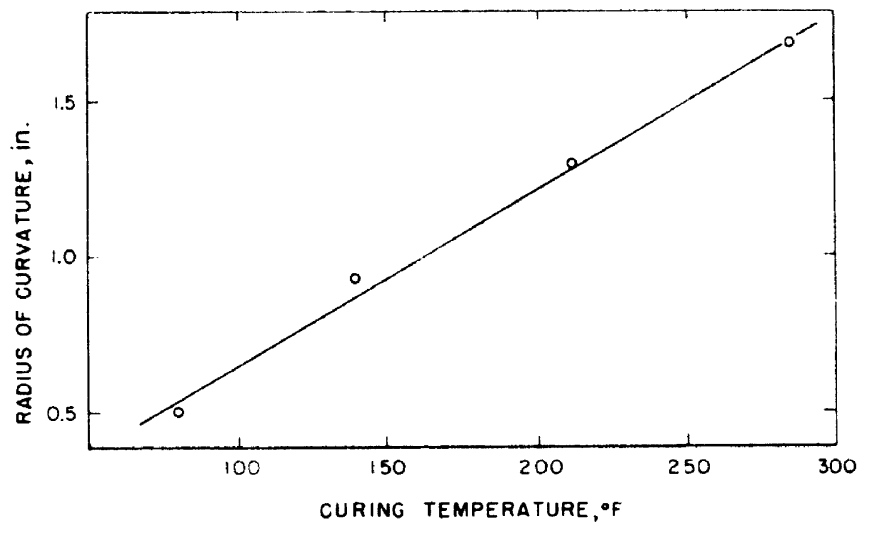

Figure 6. Effect of curing temperature on the radius of curvature required to cause cracking of a layer of $C-1$ cement when applied at a thickness of two mils to ingot iron specimens, 0.043 in. thick.

the relation between the curing temperature of the cement and the radius of curvature of the specimen at failure. The radius at failure increased linearly with the curing temperature.

The stress responsible for the cracking varies with the distance of the outer surface of the cement laver from the neutral axis of the specimen. Thus, the cement layers could have been bent through much smaller radii had the backing been foil or thin paper rather than the 0.043 in. thickness of iron. Nevertheless, the results show that room temperature drying produces maximum flexibility of the cement layer.

c. Other Properties of Ceramic Cements are Reported in Section 4

\section{Development of Gages}

\subsection{Metal-Backed Gages}

The earliest gages designed in the initial phase of this program were constructed on backings of ceramic-coated metal foil. The first design consisted of fine wires wound on a thin sheet of mica which was then sandwiched between two sheets of ceramic-coated Inconel foil of two mils thickness. In the second design the wire was wound on coated foil and this assembly then sandwiched between mica sheets. The third design, which was more successful, consisted of straight strands of wire embedded in the ceramic coating on a single sheet of foil.

Gages of the third design were constructed in the following manner: four Nichrome wires of 1-mil diameter, spaced $1 / 8$ in. apart, were drawn tightly across the face of a 2-mil Inconel strip which had been precoated with 2 mils of NBS A-418 ceramic [9]. The wires were cemented to the coated Inconel at the ends of the strip with an air-hardening cement. Next, crossovers were formed as shown schematically in figure $7 \mathrm{~A}$ by brushing on NBS coating $\mathrm{M}-60 \mathrm{~F}$ which consists of a mixture of a glass powder and a $\mathrm{Cr}-\mathrm{B}-\mathrm{Ni}$ brazing alloy [10]. After firing the specimen at $1,925^{\circ} \mathrm{F}$ for $2 \mathrm{~min}$ to mature the $\mathrm{M}-60 \mathrm{~F}$, the ends of the strip were sheared off to give the partly finished gage illustrated in figure 7B. After attaching the leads with the $M-60 \mathrm{~F}$ braze coat as shown in figure $7 \mathrm{C}$, the gage was given a final coat of A-418. The overall thickness of gages made by this technique is about 7 mils. A transverse section through the gage showing one of the wires embedded in the Cr-B-Ni alloy is shown in figure 8.

Although a gage of this type is quite rugged and therefore may find uses in certain specialized applications, it is difficult to cement and also it is relatively inflexible because of its thickness and construction. 


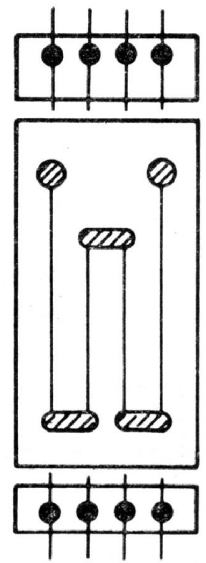

-1 in.

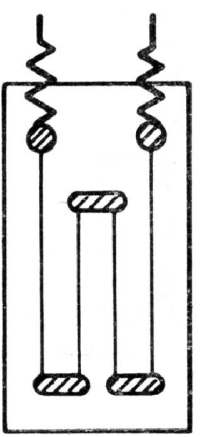

air hardening cement M-gof brazing alloy

- 0.001 in. diam NICHROME WIRE

- HEAVY LEAD WIRE

Frgure 7. Schematic drawing showing separate steps in the preparation of a gage fabricated through use of ceramicmetal braze coat $M-60 F$.

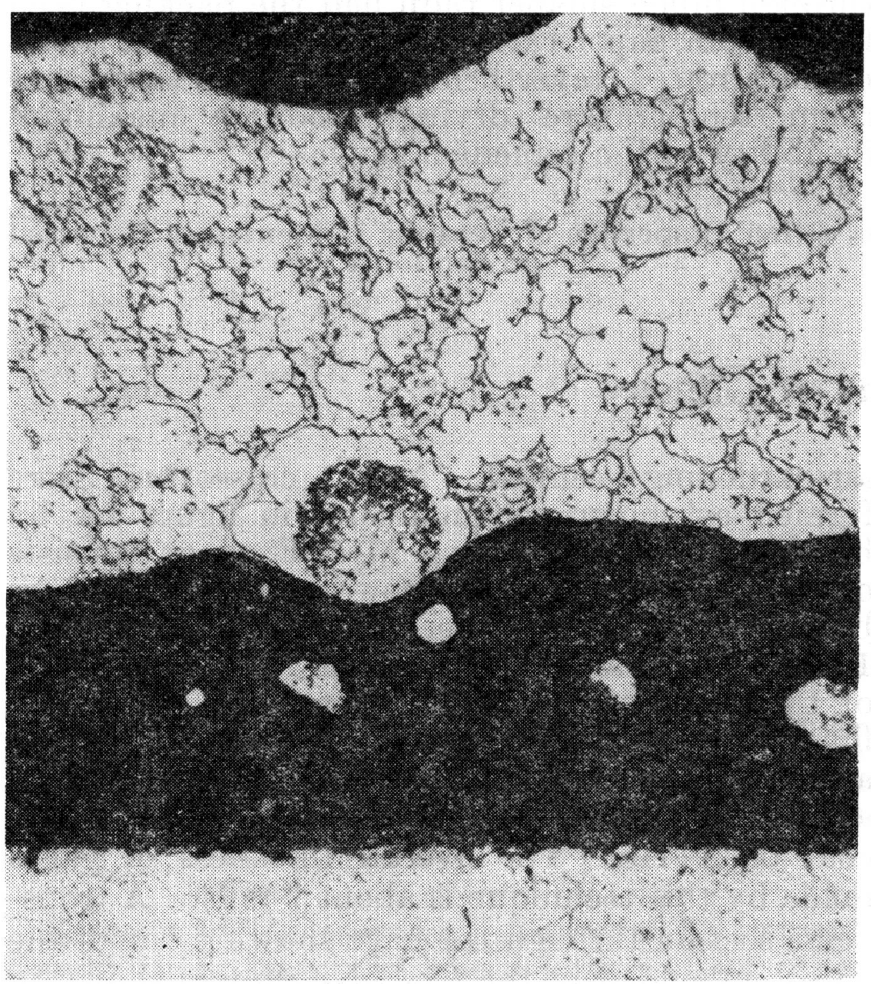

FiguRe 8. Photomicrograph of a transverse section cut through a metal-backed gage showing attachment of the 1-mil diameter Nichrome filament wire (circular area at center of micrograph) to the $\mathrm{Cr}-\mathrm{B}-\mathrm{Ni}$ alloy (upper metallic region), and also showing the separation of this alloy from the Inconel foil (lower metallic region) by a layer of ceramic coating (dark region interspersed with metallic particles). Etched with Carapella's reagent.

\subsection{Plastic-Backed Gage}

In an effort to provide more flexibility in a gage, the ceramic-coated foil backing was replaced by an ethyl cellulose sheet which had been sprayed with an air-hardening ceramic cement. Figure 9 is a detailed schematic drawing showing how the gage is fabricated. The gage is flexible enough to be bent around a radius of approximately onehalf inch without damage. The ethyl cellulose plastic backing sheet burns off during the first heat-up without any apparent disturbance to the gage or its insulation. The principal deficiency of this gage is that the leads are not firmly attached and are easily pulled away from the filament.

\subsection{Asbestos Paper-Backed Gage}

\section{a. Design and Fabrication}

In an effort to make the lead attachment more rugged and still retain the flexibility of the plasticbacked gage, another major design feature was incorporated. A highly flexible ceramic backing material was needed that would not decompose during heating and to which the lead wires could be securely fixed. A commercial asbestos paper [11] was found that appeared to fulfill the requirements. This material, which comes in a standard thickness of 3 mils, not only looks like ordinary paper, but has about the same strength and flexibility. The paper does not decompose on heating to $1,500{ }^{\circ} \mathrm{F}$ although it becomes brittle. It was found that the paper can be coated with a ceramic cement by the air-spray technique and that the resulting product is highly flexible when the cement layer is properly applied. This composite ceramic paper became the backing material for a new gage which was designated NBS 5B.

Essentially the 5B gage consists of two single strands of fine wire stretched across the coated side of the ceramic paper and spot welded to individual Inconel foil leads at one end and to a crossover strip at the other end. The construction details for a typical gage of 1-in. gage length are illustrated schematically in figure 10. Figure 11 is a photograph of the gage. When made with 1-mil Karma wire a gage of this length has a resistance of about $130 \mathrm{ohms}$, or, if 1-mil Nichrome $\mathrm{V}$ is used, the resistance is about $110 \mathrm{ohms}$.

The gage is attached to a specimen by placing the gage face down on a fresh layer of wet ceramic cement. If applied directly to a surface abraded with No. 280 grit, or finer, abrasive paper, the chances are exceptionally good that the gage will be electrically insulated from the metal surface; however, if 100 percent confidence against short circuiting is essential, then the gage should be applied over a precoated layer of cement. When many gages are being applied and a small percentage of malfunctions can be tolerated, it is frequently desirable to attach the gages without 

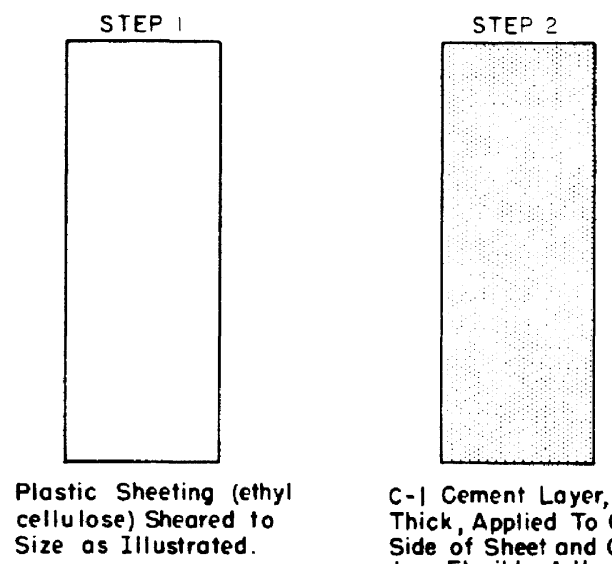

C-I Cement Loyer, .005* Thick, Applied To One Side of Sheet and Cured to a Flexible Adhering Film by Drying at Room Temperature.

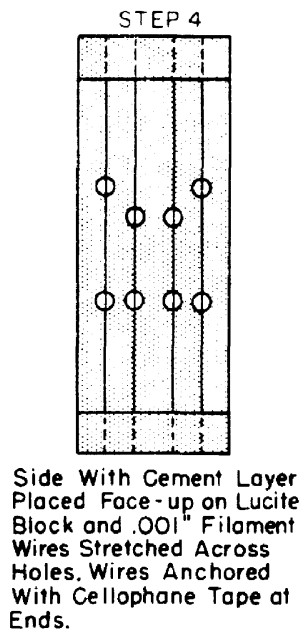

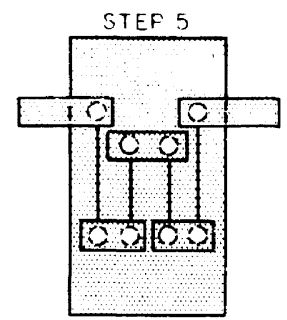

Inconel Strips,.003" Thick Glued to Cement Loyer and Eoch Filoment Wire Spot-Welded to Strips as Shown.Gage Sheared to Proper Length and Excess Filament Wires ot Ends Removed.
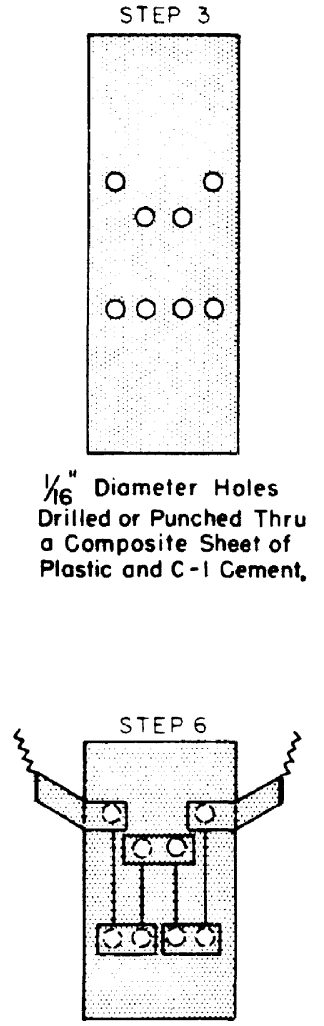

Coat of C - I Cement Applied Over Wires and Strips. Inconel Leads Bent at Angle, and .OIO"Gold (or Nichrome) Wires Brazed to Inconel. Finished Gage Con Then be Cemented to Specimen

When Needed. Plistic Sheet When Needed. Plistic
Burns Off During Use.

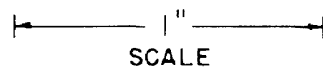

FIGURE 9. Schematic drawing showing various steps involved in the fabrication of a plastic-backed gage.

The filament wires are completely embedded in the air-irying cement after fabrication. The plastic backing sheet burns off when the gage is heated.

a precoat, thus sacrificing the certainty of nonshorting for (1) the saving of time, (2) the advantage of a thinner gage installation, and (3) a better bonded gage.

When a precoat is used, there is a tendency for the second application of the liquid bonding agent to migrate from the freshly applied cement into the porous, precured first layer. This loss of bonding agent from the wet cement may result in a poorer bond between the gage and the test specimen than is obtained when the same cement is applied directly to the metal.

\section{b. Characteristics}

From time to time during the course of the program a number of properties and characteris- tics of developmental gages were determined more for the purpose of directing future efforts than for supplying precise evaluation data. Some of those properties of the $5 \mathrm{~B}$ gage which were investigated are believed to have been determined reasonably accurately while others, particularly those involving response of the gages to strain at elevated temperatures, were evaluated by approximate methods that were considered adequate for obtaining relative values for developmental purposes.

The properties investigated are listed below. In all cases, when the gage was attached to a surface, the cement used was C-1.

(1) Gage factor. The gage factors of $5 \mathrm{~B}$ gages were determined in tension at 75 and $800{ }^{\circ} \mathrm{F}$ and for calculated strains up to $350 \mu \mathrm{in}$./in. The de- 


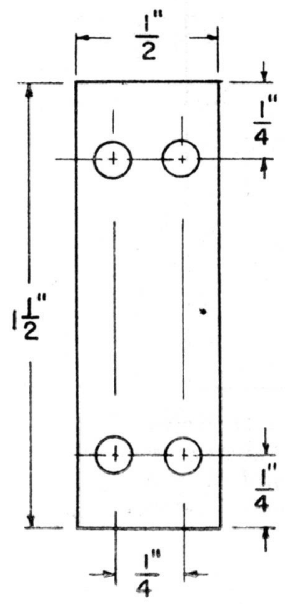

(a) $1 / 8$ in. diameter holes are punched in a strip of ceramic coated asbestos paper.

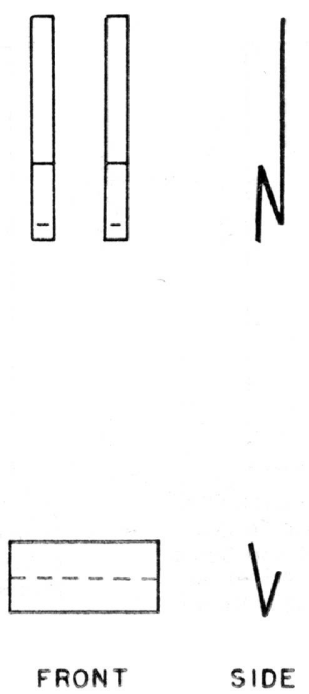

(b)

Annealed strips of 0.002 in. thick Inconel (or other heat-resisting alloy) are bent into the shapes shown above.

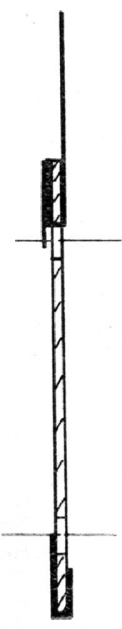

ENLARGED SIDE CUT (c)

Upper strips (leads) are inserted in upper, holes of paper while lower end of paper is placed in $V$-notch of lower strip (cross-over). Strips are then pressed flat.

Figure 10. Steps in the fabrication of the $5 B$ gage.

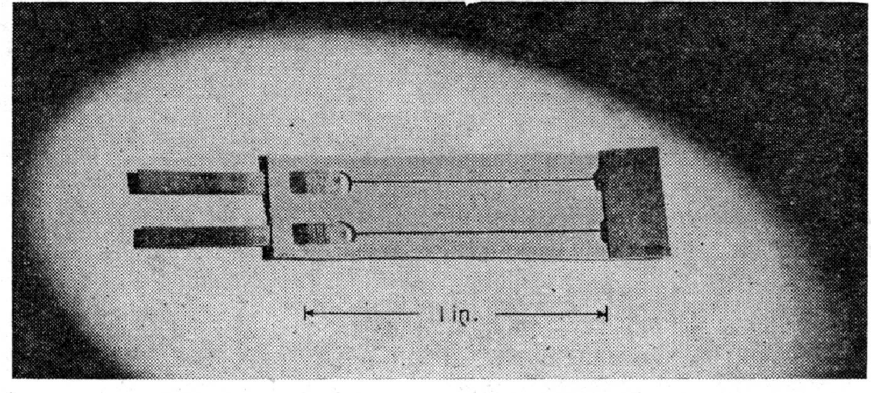

Figure 11. Completed $5 B$ gage prior to cementing, showing face of gage.

terminations were made by adding known increments of tensile loads to a heat-resisting alloy test strip with gage attached, while reading the resulting changes on a strain indicator. The gage factors were computed from the instrument readings and the known moduli of elasticity of the test alloy at the various test temperatures. Thus, the gage factor, $K$, is given by the relation $K=\epsilon_{i} \times K_{i} / \epsilon_{a}$ where $\epsilon_{i}$ is the indicated strain, $\epsilon_{a}$ the computed strain and $K_{i}$ is the gage factor setting on the instrument.

The averaged values obtained for 12 Karma wire gages were:

\begin{tabular}{c|c|c}
\hline \hline Temperature & Gage factor & $\begin{array}{l}\text { Standard } \\
\text { deviation }\end{array}$ \\
\hline $75 \mathrm{~F}^{\circ}$ & $\begin{array}{c}2.59 \\
2.22\end{array}$ & $\begin{array}{c}0.11 \\
.08\end{array}$ \\
\hline
\end{tabular}

It is of interest that the room temperature average value is the same as that obtained from gages of the $5 \mathrm{~B}$ design fabricated in another laboratory and calibrated with a Tuckerman optical strain gage [12].

(2) Effect of cement thickness on gage factor. When the $5 \mathrm{~B}$ gage was applied directly to a metal surface without a cement precoat, it was found that the gage wire was usually separated from the surface by a layer of cement approximately 0.5 mil thick. Inasmuch as some deviations from this separation distance might be expected when the gages are cemented in other laboratories, tests were made to determine the effect on gage factor of varying the cement interlayer thickness.

Gages were applied to eight stainless steel specimens with cement thicknesses ranging between 0.5 and 38.5 mils and the gage factor of each was determined at room temperature. The 
results showed no apparent correlation between the room-temperature gage factor and cement thickness.

(3) Strain response at high-strain levels. Two heat-resisting alloy specimens with $5 \mathrm{~B}$ gages attached were stressed in tension at 75 and $800^{\circ} \mathrm{F}$. In each case the specimen was stressed to 36,000 psi in 3,000 psi increments. The resulting indicated strain values are plotted in figure 12 as a function of stress. The $75^{\circ}$ stress-strain curve is within 1 percent of the theoretical curve as calculated from the known modulus of elasticity of the alloy and the $800^{\circ}$ curve is within 7 percent of the theoretical curve. Figure 12 shows that the $5 \mathrm{~B}$ gage is capable of giving strain indications up to $1,270 \mu \mathrm{in}$./in. with a high degree of linearity.

For more accurate evaluations of response at high-strain levels a set of five randomly selected gages were strained to gage failure at room temperature while being calibrated with a Tuckerman optical strain gage. The strain errors are plotted as a function of the resistance-gage readings in figure 13. It can be seen that the maximum error at an indicated strain of $4000 \mu \mathrm{in}$./in. was less than 10 percent, therefore all gages endured true strains of at least $3600 \mu \mathrm{in}$./in. At indicated strains of $3000 \mu \mathrm{in}$./in. the maximum error was less than 5 percent.

(4) Behavior of gages attached to metals of different thermal expansivities. The behavior of $5 \mathrm{~B}$ gages on three metals having widely different coefficients of thermal expansion was investigated. The three metals selected and their reported expansivities over the range 70 to $600{ }^{\circ} \mathrm{F}$ are:

\begin{tabular}{l|c}
\hline Metal & $\begin{array}{c}\text { Coefficient of linear ther- } \\
\text { mal expansion }\end{array}$ \\
\hline Aluminum alloy 2024 & $\begin{array}{c}13.7 \times 10^{-6} \text { per }{ }^{\circ} \mathrm{F} \\
7.5\end{array}$ \\
Inconel 3.2
\end{tabular}

The gages were attached to small sheet specimens with $\mathrm{C}-1$ cement and, after curing for $2 \mathrm{hr}$ at $230{ }^{\circ} \mathrm{F}$, were inserted in a furnace at $600^{\circ} \mathrm{F}$. Changes in gage resistance were recorded for a period of $90 \mathrm{~min}$, after which the specimens were removed and cooled to room temperature.

Figure 14 is a graph of the resulting data. Each point is the average of from 4 to 6 determinations. The effect of the expansion of the base metal as the specimen heats from room temperature to $600^{\circ} \mathrm{F}$ is obvious. The drift behavior at temperature was of a comparable magnitude for all three metals: 150,170 , and $100 \mu \mathrm{in}$./in. for molybdenum, Inconel, and the aluminum alloy, respectively. On cooling to room temperature, all of the gages exhibited resistance values considerably higher than the initial value. This zero shift is probably associated with the behavior of the cement and will be discussed in section $4.4 \mathrm{~b}$.

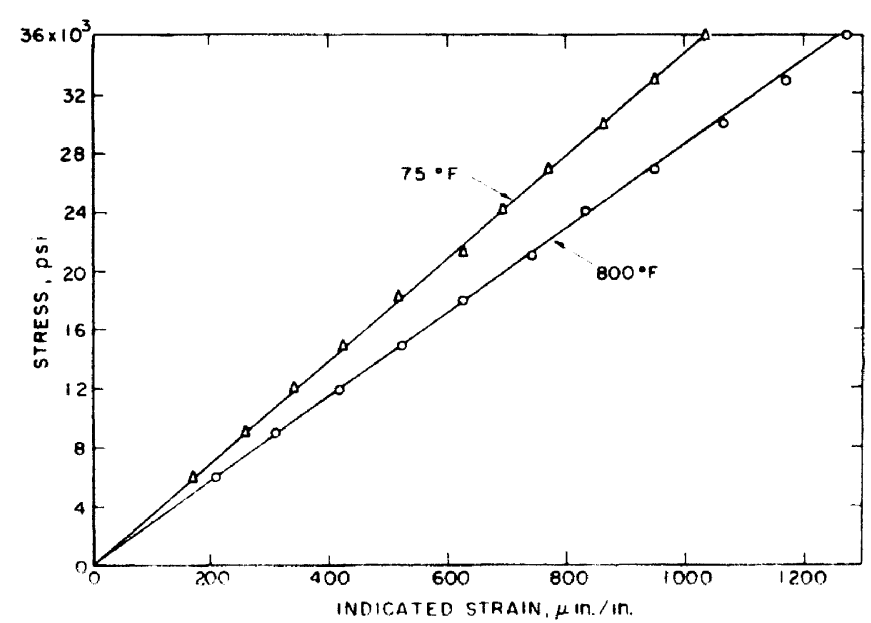

FIGURE 12. Stress-strain curves obtained with $5 B$ gages cemented to heat-resisting alloy test strips with $C-1$ cement.

The averaged values of gage factor $\left(2.59\right.$ to $75^{\circ} \mathrm{F}$ and 2.22 at $\left.800^{\circ} \mathrm{F}\right)$ which were previously determined for the $5 \mathrm{~B}$ gage at very low strains were used to obtain these data.

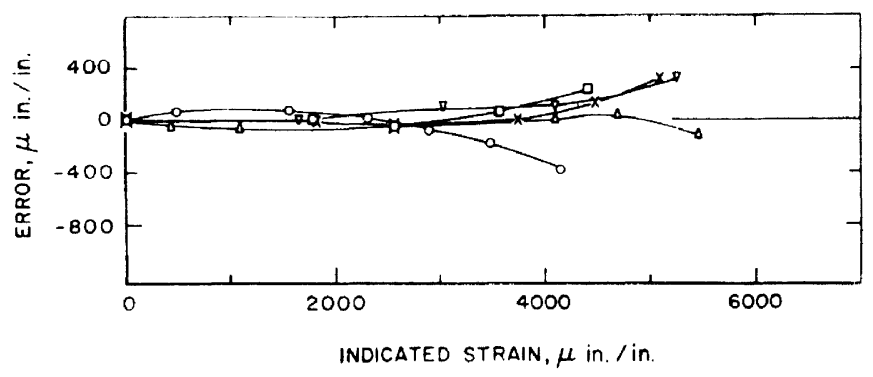

Figure 13. The errors in response of five $N B S 5 B$ resistance-type strain gages tested to high strain levels at room temperature.

True strains were obtained with a Tuckerman optical strain gage, from which the errors of the resistence gages were computed.

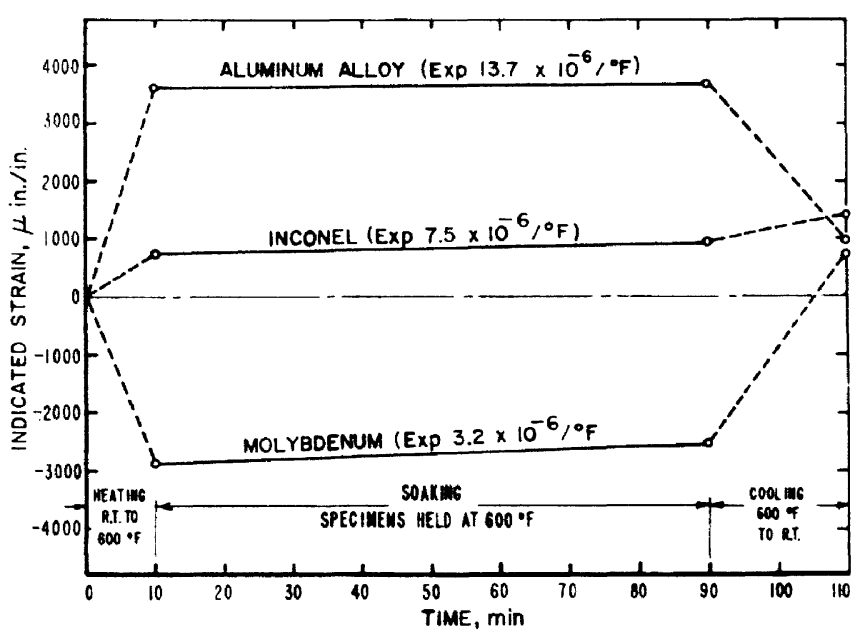

FIGURE 14. Indicated strain from gages of the $5 B$ design when attached with $C-1$ cement to metals of widely differing thermal expansivities and preheated to $230^{\circ} \mathrm{F}$ prior to testing.

Each specimen with gage attached was heated rapidly by inserting into a furnace at $600^{\circ} \mathrm{F}$. After 80 min. at temporature the specimens were removed from furnace and cooled in air. Each curve is the average of from 4 to 6 determinations. 
(5) Resistance to ground. The electrical resistance of the cement or other insulating material separating the strain gage circuit from the substrate is hereinafter referred to as the "resistance to ground" or the "leakage resistance." The resistance to ground is principally a function of both the resistivity of the cement and the thickness of the cement interlayer, but is also dependent on the gage design. Inasmuch as the $5 \mathrm{~B}$ gage has a comparatively large surface area and is normally applied without a precoat of cement on the specimen, some measurements were made of its resistance to ground at a series of temperatures up to $1,300^{\circ} \mathrm{F}$. Gages were cemented to specimens with $\mathrm{C}-1$ cement, which was cured at $230^{\circ} \mathrm{F}$ for $2 \mathrm{hr}$. The assemblies were then heated and held at the desired temperature until the resistance to ground reached a constant value. The data for two gages are shown in figure 15.

(6) Effect of surface roughness on gage response. Three groups consisting of three specimens each of type 321 stainless steel were prepared with widely differing degrees of surface roughness. The specimens of one group were sandblasted with a 60 mesh sand, those of a second group were abraded with No. 280 grit silicon carbide abrasive paper, and the specimens of a third group were electropolished. Also, two groups of aluminum alloy 2024 specimens were sandblasted and abraded as described above. Gages of the 5B design were attached to the metal specimens with $\mathrm{C}-1$ cement which, after air drying, was cured at $220^{\circ} \mathrm{F}$. Each specimen was heat cycled from room temperature to $600{ }^{\circ} \mathrm{F}$ a total of six times and the resistance change for each heating cycle was measured. Uncemented gages were subjected to the same cycling treatment and by subtracting the resistance changes of the uncemented gages from those of the cemented gages, values were obtained that were independent of the tempcrature coefficient of resistance; i.e., each value represents the thermal strain in the filament that resulted from differential changes in dimensions of the wire, of the metal specimen, and of the cement used for attaching the gage. Figure 16 is a plot of the resulting data. The small changes of indicated struin related to differences in surface preparation of stainless steel are not considered significant. In the case of the aluminum alloy, the thermal strains of gages on the mildly abraded specimens were less than would be anticipated from thermal expansion differences only; however gages on sandblasted specimens showed strains unaccountably greater than would be expected. The implication from these data is that surface roughness affects the degree of strain transmission at high-strain levels, but that at low-strain levels sufficient bond between the cement and the alloy is achieved even when the specimen surface has a high polish.

(7) Effect of thermal cycling on gage behavior. Figure 16 shows that at low-strain levels gage response was stable after the first cycle. The

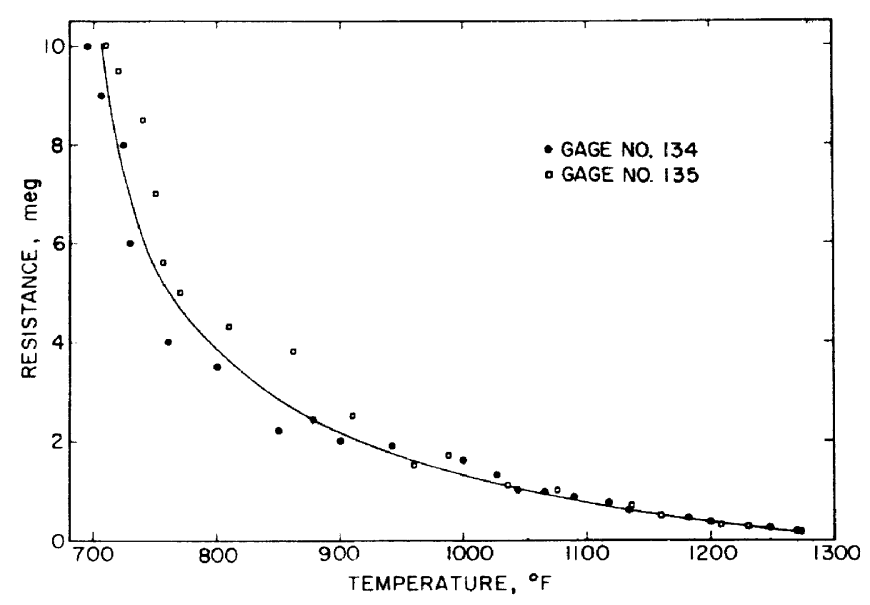

FiguRE 15. Resistance to ground measurements for two $5 B$ gages attached to an Inconel specimen with $C-1$ cement.

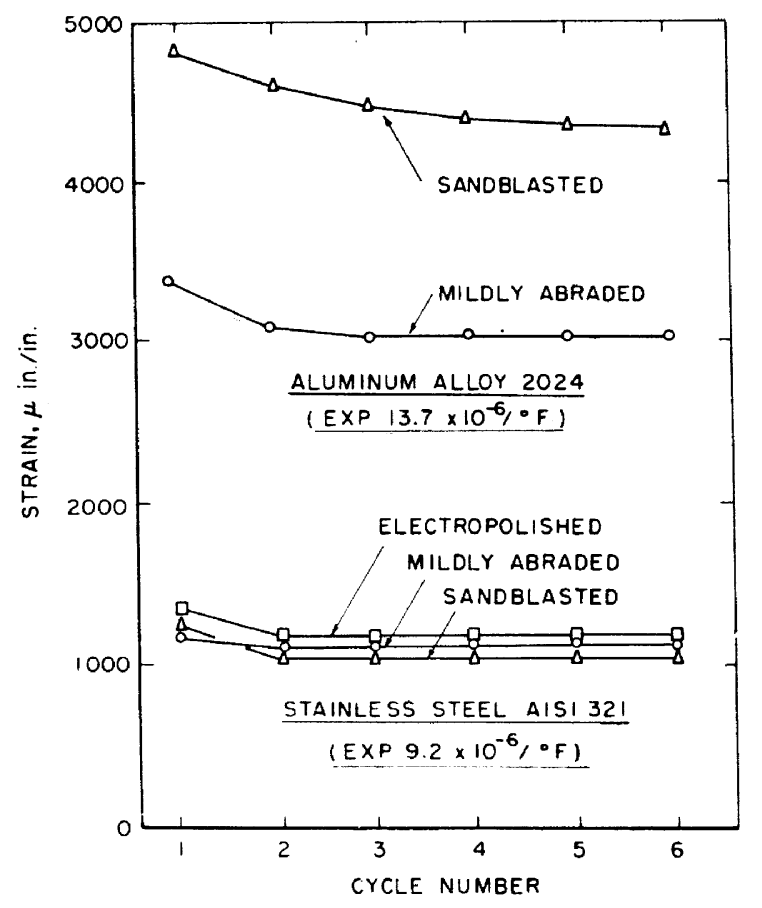

Figure 16. Thermal strains transmitted to $5 B$ gages when alloy specimens with gages attached were heated from room temperature to $600^{\circ} \mathrm{F}$.

Cycle numbers refer to successive heatings.

behavior on the first cycle is believed to be due to improper curing of the cement and is discussed in a later section (4.4).

\subsection{Unbacked Wire-Grid Gages}

The need for better electrical insulation at the higher temperatures led to the development of the unbacked wire-grid gage (design No. 6) and eventually to the ceramic-coated gage (No. 6A). As is well known, the electrical resistivity of ceramics decreases with increasing temperature. 
At operating temperatures of about $1,000{ }^{\circ} \mathrm{F}$ and higher most of the known ceramic strain gage cements become so electrically conducting as to seriously affect the response of a strain gage. It appeared that the most promising solution to the problem was to provide electrical insulation independent of the bonding cement. This could be done by precoating the wire with an impervious highly insulative ceramic material. However, none of the available gages was suitable for applying a fused-on coating; therefore, a special type of gage needed to be developed.

\section{a. Design and Fabrication}

A gage was needed which would maintain its grid configuration free of any backing or embedding material. As a result, a technique was developed whereby the gage wire is given a permanent set by stretch-forming. The procedure consists of winding the gage wire, with leads attached, on pins inserted in holes in a two-piece variablelength jig, then stretching the grid in the axial direction by elongating the jig with a micrometer screw attachment. An alternate variation of stiffening the grid is to heat the wire by passing an electric current through it and, while the grid is elongated due to thermal expansion, the slack is taken out by extending the jig. Then, as the wire is allowed to cool, it becomes plastically deformed as a result of restrained thermal contraction. After taping the leads to a plastic carrier with adhesive tape, the gage may then be removed from the jig and handled by its leads without altering the grid shape. The gage is now ready to be ceramic coated, or if desired, it can be used uncoated.

\section{b. Geramic-Goated Gage}

Very fine wires are not amenable to being coated by the usual ceramic coating techniques in which the article is either dipped in a slip (finely divided coating material suspended in a liquid) or the slip is sprayed onto the article, followed in both cases by high-temperature fusion. An alternate method of applying the slip is by electrophoresis. In this process, finely divided particles which are electrically charged with respect to a dispersing medium, are deposited on an electrode under the influence of an electrical potential. This method is particularly suitable for coating strain gages because of (1) the uniformity with which the coating can be applied, (2) the absence of mechanical force on fragile parts during deposition, and (3) optional codeposition of two or more materials simultaneously.

The technique was adapted to coating of the unbacked gage by immersing the wire grid and a portion of the gage leads in a dielectric liquid containing suspended particles of a pulverized ceramic material. The gage was made the electrode which received the charged particles when a potential was applied. A number of coating materials were tried, but the most successful coating was a commercial high-temperature ceramic frit having the following computed oxide composition:

\begin{tabular}{c|c|c|c}
\hline \hline Oxide & Wt. percent & Oxide & Wt. percent \\
\cline { 2 - 3 } & & & \\
\hline $\mathrm{SiO}_{2}$ & 48.0 & $\mathrm{Al}_{2} \mathrm{O}_{3}$ & 3.6 \\
$\mathrm{BaO}$ & 18.2 & $\mathrm{Na}_{2} \mathrm{O}$ & 2.6 \\
$\mathrm{TiO}_{2}$ & 8.4 & $\mathrm{~K}_{2} \mathrm{O}$ & 1.1 \\
$\mathrm{~B}_{2} \mathrm{O}_{3}$ & 7.9 & $\mathrm{CuO}$ & 1.1 \\
$\mathrm{ZrO}$ & 4.7 & $\mathrm{~F}_{2}$ & 0.1 \\
$\mathrm{ZnO}$ & 4.3 & $-\ldots-.-$ \\
\hline
\end{tabular}

The frit was ball-milled dry for $24 \mathrm{hr}$, then the -325 mesh fraction was mixed with isopropyl alcohol in the ratio of $200 \mathrm{~g} /$ liter. The gage (anode) was immersed in the suspension 1 in. from the cathode (stainless steel) and a $200 \mathrm{v}$ potential was applied to the circuit for $0.2 \mathrm{sec}$. The resulting deposit of particles was dried and fused to a vitreous coating of approximately 1-mil thickness by firing for $4 \mathrm{~min}$ at $1,500{ }^{\circ} \mathrm{F}$. Figure 17 is a photograph of a $120-\mathrm{ohm}$ ceramiccoated gage.

After bending the leads out of the plane of the grid, the gage is ready for use. The bend is made about one-eighth of an inch from the junction with the wire so that a portion of the leads will be embedded in cement. The gage can be applied to a test surface by laying the grid down on a thin layer of wet cement, no precoat being required.

\section{c. Characteristics}

These gages have been made in lengths of $5 / 16$ to $3 / 4$ in. using 1 -mil wire. Longer gage lengths tend to require a support for the grid, while shorter lengths require too many loops to achieve the

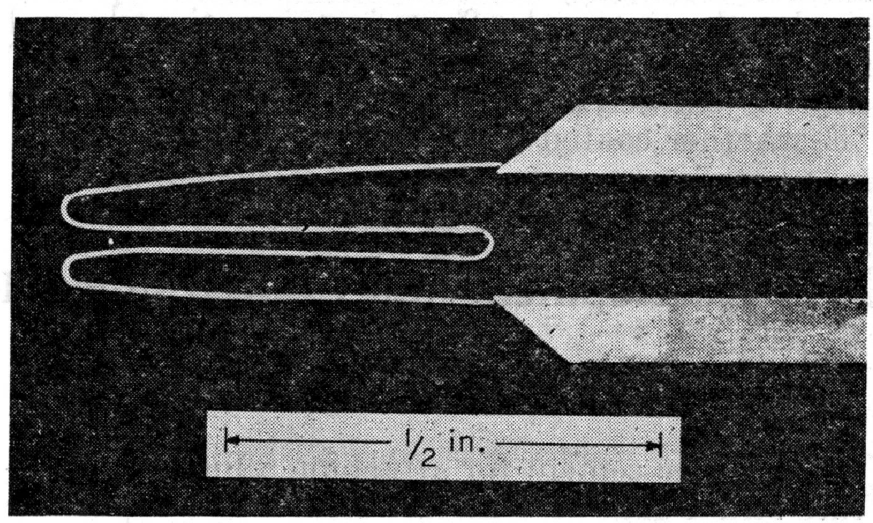

Figure 17. Photograph of a ceramic-coated unbacked gage (design no. 6A).

The gage length is one-half inch and the resistance of the gage is $120 \mathrm{ohms}$. 
necessary resistance. Grids with five loops (six legs) nave been made, but the three-loop gage (fig. 17) is preferable.

These gages suffer from the fact that they can be used only on plane surfaces; also the ceramiccoated gage is difficult to make and is very fragile. No accurate evaluations have been made of the gage; however, a few trials have shown that the gage can be cemented easily to a test strip and when the strip is pulled in tension the gage response is in the approximately correct strain range.

Figure 18 shows the strain response of an unbacked, uncoated gage (design No. 6) cemented to a test strip with NBS cement No. X-142 and strained in tension at $600{ }^{\circ} \mathrm{F}$. The specimen was strained to $470 \mu \mathrm{in}$./in. and relaxed to 190 , strained again to 470 and relaxed to 190 , then strained to 1130 and relaxed to zero, and finally strained again to 1130 and relaxed to zero. For clarity in reading the graph, the beginning of each cycle after the first has been shifted to the right by 100 units. The actual strain was computed from the stress applied to the specimen and its known modulus of elasticity at the test temperature. The gage response was measured with a strain indicator. The instrument was zeroed only once, at the beginning of the test; thus it can be seen that the total zero shift was only $25 \mu \mathrm{in}$./in. Another gage of the same type, but bonded with cement $\mathrm{C}-1$, was tested and gave comparable results on the fourth cycle; however, the preliminary cycles were considerably more erratic.

One of the effects of applying a fused ceramic coating to the gage wire was demonstrated by measuring the drift of coated and uncoated wires heated in air. One mil strands of Nichrome V and Armour Research Foundation's Alloy D, some uncoated and some coated with a ceramic frit were heated to $1,000,1,200$, and $1,400^{\circ} \mathrm{F}$ and held for $2 \mathrm{hr}$ while drift measurements were made. Figure 19 shows the results. The negative drift, (decrease in resistance) of Nichrome $V$ at $1,000^{\circ} \mathrm{F}$ is apparently due to a time-temperature-dependent structural change taking place in the alloy; the positive drift of the uncoated wires is attributed to surface oxidation, the effect of which completely masks the internal effect just mentioned, and results in a net increase in resistance. ARF Alloy $D$ showed negligible drift at 1,200 and 1,400 ${ }^{\circ} \mathrm{F}$, whether coated or uncoated.

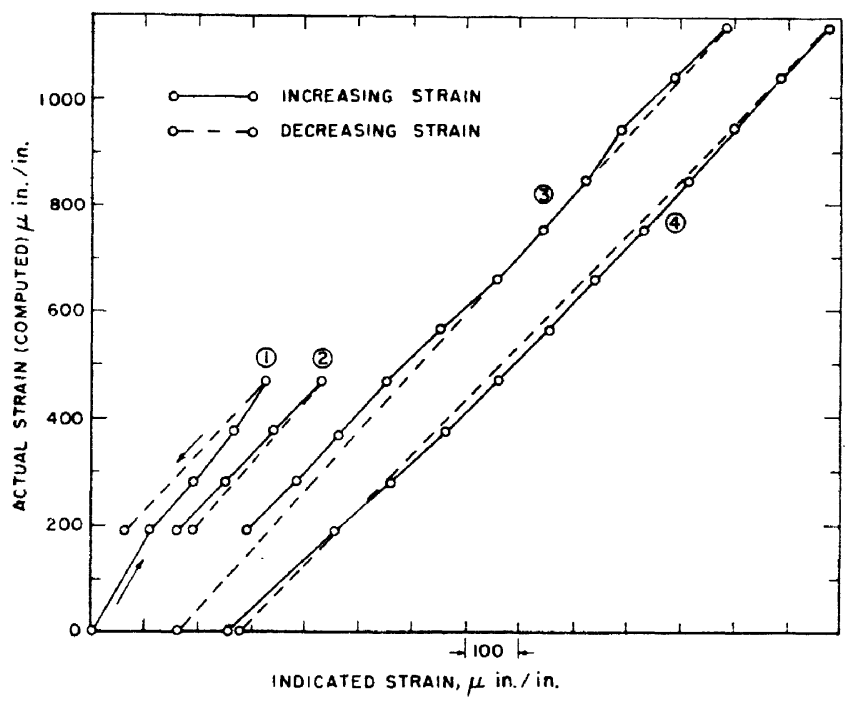

FIGURE 18. Four strain cycles for an unbacked gage (design no. 6) bonded with NBS X-142 cement and tested in tension at $600^{\circ} \mathrm{F}$.

The beginning point of the second cycle is the end point of the first cycle, except shifted 100 units to the right. Likewise for the third and fourth cycles.

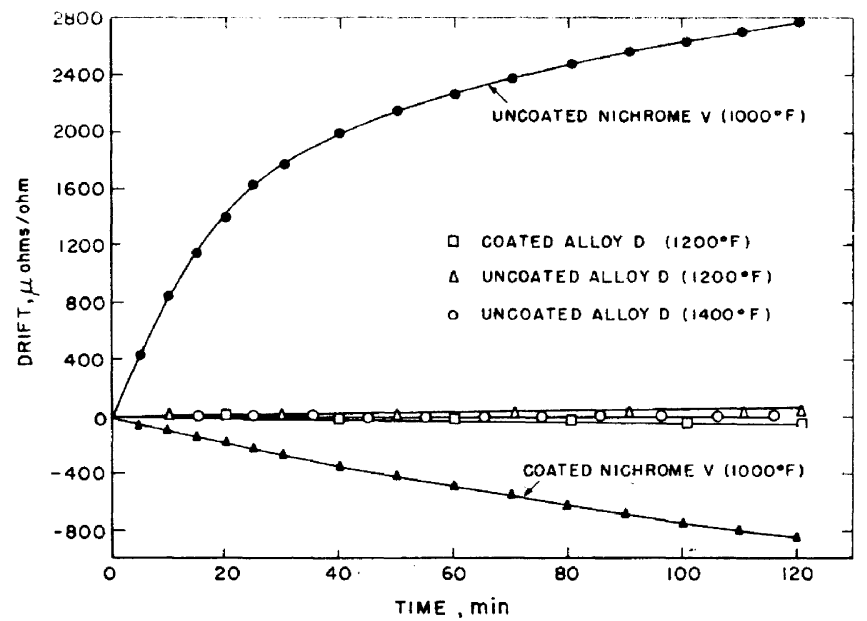

FIgURE 19. Drift of coated and uncoated Nichrome $V$ and Armour Research Foundation Alloy $D$ wires.

The beneficial value of a ceramic coating as an electrical insulator is discussed in section 4.4.

\section{Development and Evaluation of High-Temperature Strain Gage Cements}

\subsection{Resistivity}

A ceramic cement for attaching a high-temperature strain gage to a metal surface should provide a suitable bond between the strain-sensitive element and the underlying metal, and in addition, it should have a high-electrical resistance. Many of the cements in current use have been found to provide an adequate bond, but unfortunately they all show appreciable electrical leakage at elevated temperatures. Such leakage affects gage response, and therefore limits the usefulness of the gage.

In an attempt to overcome this deficiency, an investigation was made of the resistance-temperature characteristics of several promising cement materials with the hope that by blending high- 
purity oxides with selected bonding media, cements having very high resistivities could be developed.

A number of ceramic materials, which a review of the literature indicated had high resistances, were obtained as powders in the highest purity available. These ceramics included alumina, beryllia, magnesia, thoria, silica, and mica. The bonding agents investigated were orthophosphoric acid, monoaluminum phosphate, calcium aluminate, potassium silicate, silica gel, and clay. Experimental cements were prepared by mixing in various proportions each of the six bonding agents with one or more of the different fillers and adding water, where necessary, to produce the desired consistency. A rapid qualitative screening test was employed to eliminate those compositions that showed insufficient adhesiveness, unsatisfactory hardness, or excessive shrinkage after curing at $600{ }^{\circ} \mathrm{F}$. Then the more promising compositions were evaluated for leakage resistance at elevated temperatures.

Measurements were made on cement specimens placed between hollow cylindrical electrodes as shown in figure 20. Specimen thickness was controlled by inserting 0.008 in. thick separators between the tabs of the top and bottom electrodes. These separators were removed as soon as the cement reached a "leather-hard" condition after which the specimens were dried overnight at room temperature, and then cured for $1 \mathrm{hr}$ at $600{ }^{\circ} \mathrm{F}$. Resistance measurements were made at $25{ }^{\circ} \mathrm{F}$ intervals from room temperature to $1,800^{\circ} \mathrm{F}$ with a $1.5 \mathrm{v} \mathrm{d}-\mathrm{c}$ ohmmeter. The heating rate was $15^{\circ} \mathrm{F} / \mathrm{min}$. In addition, a few specimens were tested through a second heating and cooling cycle. All showed increases in resistance at comparable temperatures during the second cycle. Resistivities were computed from the measured resistances and the known specimen dimensions. (Further details of the test apparatus and procedure are given in ref [13].)

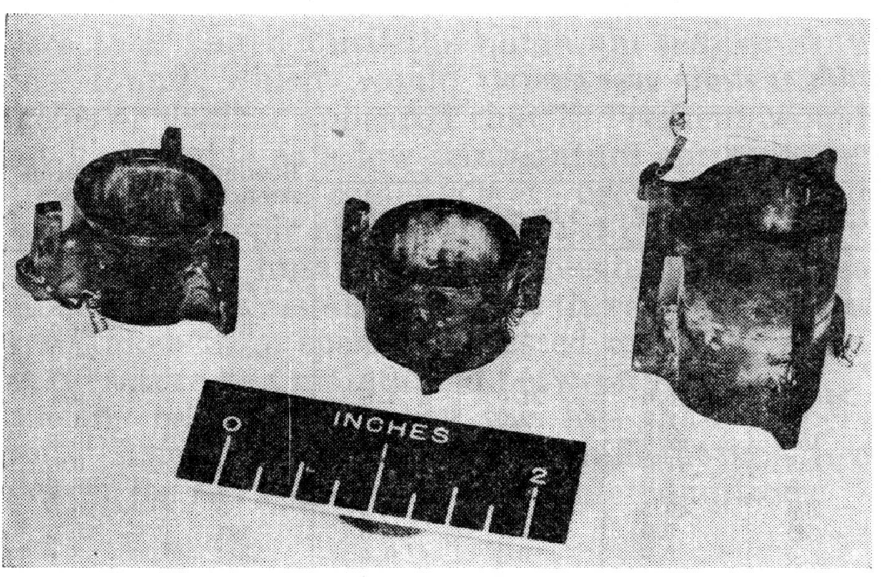

Figure 20. Photograph of hollow cylindrical electrodes used for measuring the resistivities of cements.

Shown left to right are: an inverted top electrode, a bottom electrode, and a set of electrodes in test alinement with a cement layer sandwiched between them. Three legs on each electrode are used for obtaining a cement layer of uniform thickness; the legs are separated by an air gap during test.
Several of the new compositions had resistivities in the 1,200 to $1,800^{\circ} \mathrm{F}$ temperature range higher than any of the known commercial cements, yet they were all susceptible to low resistivities in the intermediate temperature range during the first heating schedule. Such behavior is believed to rasult from the fact that the cements were not completely "cured", although they were preheated for $1 \mathrm{hr}$ at $600^{\circ} \mathrm{F}$. This intermediate temperature effect is not repeated on second or subsequent heating cycles, but unfortunately, the primary interest in a strain gage cement for many applications is its behavior on the first heating.

A composition was developed that minimizes the aforementioned effect. In addition, it maintains the highest resistivity in the 800 to $1,800{ }^{\circ} \mathrm{F}$ range of any of the experimental or commercial cements tested. In table 2 the resistivity of this cement, designated $\mathrm{X}-142$, may be compared with the resistivities of all commercial cements measured during the course of this program. ${ }^{4}$

The batch composition of strain gage cement $\mathrm{X}-142$ follows:

\begin{tabular}{l|c}
\hline \multicolumn{1}{c|}{ Ingredient } & $\begin{array}{c}\text { Parts by } \\
\text { weight }\end{array}$ \\
\hline Alumina a & 100 \\
Silica (crystalline) $)^{\mathrm{b}}$ & 100 \\
Chromic anhydride (CrO $\left.{ }_{3}\right)$ & 2.5 \\
Colloidal silica solution ${ }^{\circ}$ & 30 \\
Orthophosphoric acid (85.7\%, ACS) & \\
\hline
\end{tabular}

a $0.3 \mu$ approximate particle size.

- Ludox, S.M. grade (available from E. I. duPont de Nemours, Grasselli Chemicals Dept., Wilmington, Del.).

Inasmuch as ceramic cements are polarizable ionic conductors, their resistivities are dependent not only on temperature, but also on the magnitude and time of passage of a direct current through them. For this reason the resistivities as herein reported cannot be considered as absolute values, but rather as relative values applicable only to these particular test conditions. However, the fact that these values do give fairly reliable indications of the leakage resistance of a cement in a normal strain gage application is illustrated in figure 21, which shows good qualitative agreement between the changes in resistivity values of two cements and the changes in resistance to ground measurements made on two 5B gages cemented to specimens with each of these cements.

\subsection{Strength}

Upon completion of the resistance measurements of each specimen, the room temperature bond strength of the cement was determined by

4 Only those cements which developed a measurable bond strength were included in resistivity comparisons, inasmuch as the extent of cementelectrode contact of the others was questionable. Intimate contact over the entire electrode area is obviously essential to good resistance measurements. 


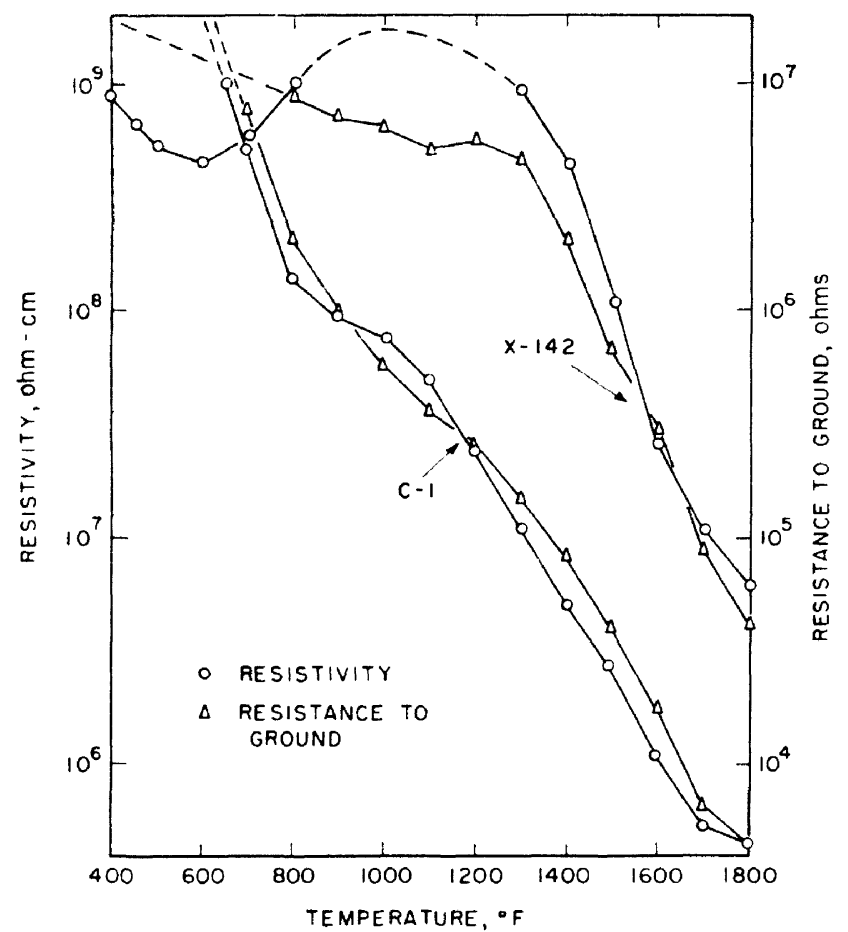

FiguRE 21. The resistivity and resistance to ground of cement $X-142$ compared with those of commercial cement (1-1.

The average cement thickness of the resistance to ground specimens was 1.6 mils for $\mathrm{X}-142$ and 3.7 mils for $\mathrm{C}-1$. (Dashed lines indicate uncertain region.)

means of a cantilever-type bending test. From the amount of force required to break the electrodes (see fig. 20) apart, and the dimensions of the system, the approximate critical bending stress was calculated. This procedure gave a value for the cohesive strength if the break occurred in the cement; otherwise the value obtained was a measure of the bond strength between the metal and the cement. The averaged strength values of two or more specimens per cement are shown in table 2 .
After air drying and even after heating to intermediate temperatures, cement $\mathrm{X}-142$ is quite soft compared to many other cements; yet, after heating to $1,800^{\circ} \mathrm{F}$, it develops reasonably good bond strength $(270 \mathrm{psi})$. It is not known what effects the variations in hardness and strength of a cement have on strain transmission, although it would seem that good strength is essential to withstand high-strain levels. The fact that cement $\mathrm{X}-142$ is capable of transmitting strains of intermediate level was shown in figure 18 .

\subsection{Hygroscopicity}

The moisture resistance of several strain gage cements at room temperature was determined by measuring the weight gain of specimens exposed to a relative humidity of 93 percent for $24 \mathrm{hr}$. The specimens used for the test consisted of layers of cement about 0.01 in. thick spread out over an area of one-half square inch on a metal backing. Curing consisted of air drying for $16 \mathrm{hr}$ and heating to $220^{\circ} \mathrm{F}$ for $1 \mathrm{hr}$. The 93 percent relative humidity was produced by a saturated solution of potassium nitrate in a closed container maintained at a temperature of $73 \pm 4^{\circ} \mathrm{F}$ (14). The results are shown in table 2 .

It can be seen that cements $\mathrm{C}-6$ and $\mathrm{C}-13$, which are bonded with a silicone resin absorbed the least amount of moisture (0.6 and 0.7 percent respectively). The silica-containing phosphate types of cement sorbed from 5.8 percent for $\mathrm{X}-142$ to 24.9 percent for $\mathrm{C}-1$ and $\mathrm{C}-4$. The effect of moisture on the behavior of cements is discussed in the next section.

\subsection{Minimum Curing Temperature}

Because of the interest in low-temperature setting cements, a study was made of the reactions taking place as a strain gage cement is cured, and the effects of those reactions on gage response.

TABLE 2. Some measured properties of strain gage cements

\begin{tabular}{|c|c|c|c|c|c|c|c|c|c|c|}
\hline & $400^{\circ} \mathrm{F}$ & $600^{\circ} \mathrm{F}$ & $800^{\circ} \mathrm{F}$ & $1,000^{\circ} \mathrm{F}$ & $1,200^{\circ} \mathrm{F}$ & $1,400^{\circ} \mathrm{F}$ & $1,600^{\circ} \mathrm{F}$ & $1,800^{\circ} \mathrm{F}$ & $\begin{array}{l}\text { Bending } \\
\text { strength b }\end{array}$ & $\underset{\text { icity o }}{\text { Hygroscop }}$ \\
\hline
\end{tabular}

a Measured at a heating rate of $15^{\circ} \mathrm{F}$ per minute for specimens that had been cured for 1 hr at $600^{\circ} \mathrm{F}$ prior to testing.

c Increase in weight of cements as a result of water pickup when specimens, b Measured at reen previously which had been preheated to $220^{\circ} \mathrm{F}$, were exposed for $24 \mathrm{hrs}$ to an atmosphere heated to $1,800^{\circ} \mathrm{F}$ for testing of resistivity. of 93 percent relative humidity at 73 , $\mathrm{F}$. 
The two goals of the study were to determine (1) the cause of cement instability and (2) the minimum thermal pretreatment required to make a cemented strain gage reproducible on repeated cycles from room temperature to selected elevated temperatures.

Briefly, the experimental procedure consisted of cementing strain gages to stainless steel specimens, preheating the specimens to various temperatures, and then measuring the resistance changes of the gages during repeated temperature cycles. Specimens were cycled between 75 and $600^{\circ} \mathrm{F}$ at a rate of either $15^{\circ} \mathrm{F} / \mathrm{min}$ or $150^{\circ} \mathrm{F} / \mathrm{min}$. In addition, a few specimens were cycled between 75 and $800^{\circ} \mathrm{F}$ at a rate of $150^{\circ} \mathrm{F} / \mathrm{min}$.

The criterion that was used to decide whether or not a cement was properly cured was to determine the degree of repeatability between the temperature-resistance curves of the first and second cycles. The maximum permissible resistance spread was arbitrarily set at $300 \mu \mathrm{ohms} / \mathrm{ohm}$ which for a strain gage having a gage factor of 2.4 would be equivalent to an apparent strain of $125 \mu \mathrm{in}$./in. For various gage installations, however, the error might be larger or smaller than $125 \mu \mathrm{in}$./in. depending on such factors as type of gage and thickness of the cement precoat.

A total of 12 different cements were tested and numerous determinations were made for each cement. First, a stainless steel specimen (2.0 in. by 0.75 in. by 0.043 in.) was uniformly precoated with a 3-mil layer of a cement. Then the gage, which consisted of a 1-in. long, $70 \mathrm{ohm}$ straight strand of Karma wire spot welded to Inconel ribbon leads, was cemented over the precoat. After air drying for $16 \mathrm{hr}$, the specimen was preheated for $2 \mathrm{hr}$ at $220^{\circ} \mathrm{F}$. Next, the specimen was temperature-cycled twice or more while the apparent gage resistance was measured at $25^{\circ} \mathrm{F}$ intervals. This procedure was repeated for a second specimen, except that the preheat temperature was either raised or lowered as indicated by the results of the first test. Additional specimens were then tested until the minimum temperature was found which would result in repeatable cycles or until it appeared that the cement would not be suitable as a low-temperature curing type.

Several of these cements were previously found to be hygroscopic and it was noted in preliminary tests that high-humidity conditions had an adverse effect on the resistance values; therefore, all data were taken from specimens tested while the room temperature was maintained between 72 and $82^{\circ} \mathrm{F}$ and the relative humidity was less than 45 percent. There appeared to be no significant moisture pickup by the cements under these conditions.

\section{a. Stability of Cements on Slow and Rapid Heating to $600^{\circ} \mathrm{F}$}

Figure 22 shows the temperature-resistance curves for a gage cemented with a sodium silicate type of cement and heated to $600{ }^{\circ} \mathrm{F}$ at a rate of

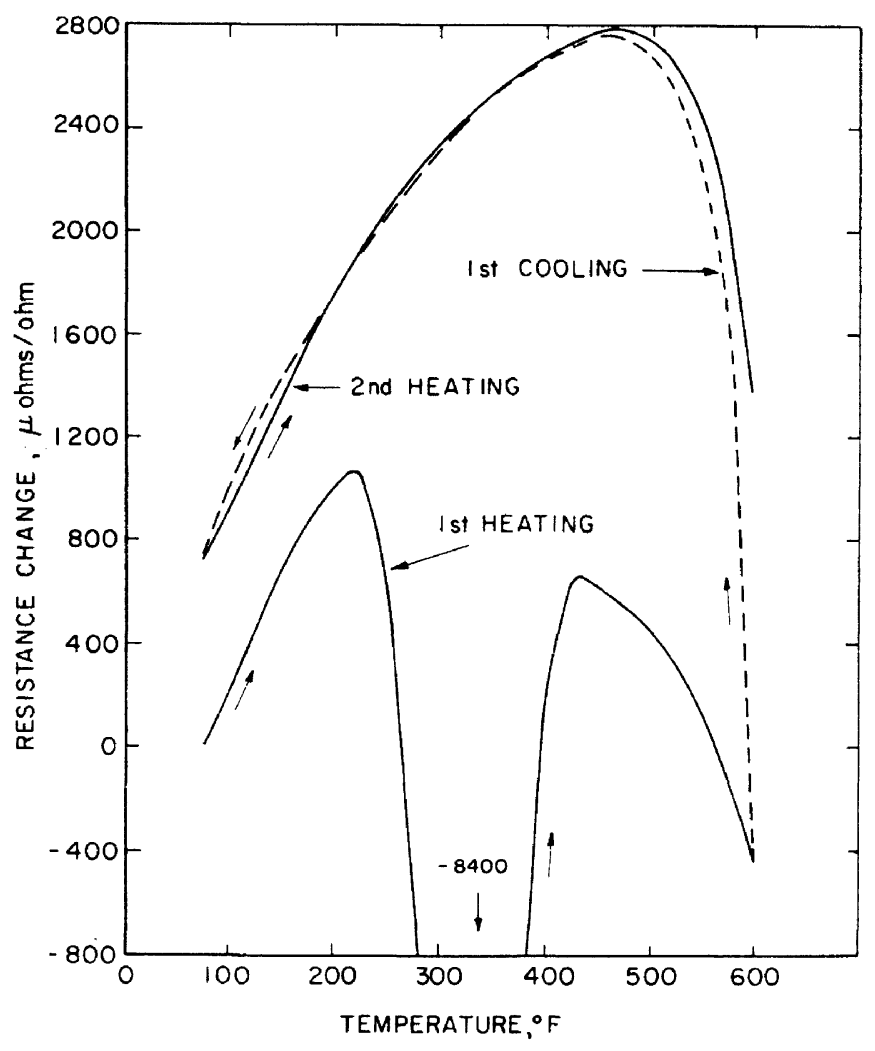

Frgure 22. Heating and cooling curves at $15^{\circ} \mathrm{F} / \mathrm{min}$ for a gage cemented with a sodium silicate cement.

Specimen was preheated for $2 \mathrm{hr}$ at $250^{\circ} \mathrm{F}$. The ordinate is the apparent resistance change of the gage wire caused by leakage through the cement.

$15{ }^{\circ} \mathrm{F} / \mathrm{min}$. The manufacturer of this cement states that it will cure at 150 to $180{ }^{\circ} \mathrm{F}$, but it is obvious that even after $2 \mathrm{hr}$ at $250^{\circ} \mathrm{F}$ the leakage resistance of the cement lacks stability. It will also be noted that the shape of the second heating curve indicates that the cement becomes very conductive above about $500^{\circ} \mathrm{F}$.

None of the cements tested was found to stabilize at room temperature; however, two cements, which are believed to contain potassium silicate as the binder, gave reproducible results after preheating for $2 \mathrm{hr}$ at only $130^{\circ} \mathrm{F}$. The curves for these cements are shown in figure 23 . All of the other cements tested, including the phosphate types and the silicone resin types required preheating at $220^{\circ} \mathrm{F}$ or higher to give comparable results.

Usually the first two heating curves, only, were determined, as it was found that large variations occurred only between the first and second cycles. The small variations which occurred between the second and subsequent cycles may be due mainly to drift of the wire. Apparently, the first heating to $600{ }^{\circ} \mathrm{F}$ completely stabilizes these cements with respect to subsequent heatings to $600^{\circ} \mathrm{F}$.

Specimens of six of the cements were tested at a heating rate of $150^{\circ} \mathrm{F} / \mathrm{min}$. The two potassium silicates and one of the phosphates behaved nearly the same as they did at the slower rate of $15^{\circ} \mathrm{F} /$ min. The other three cements required a higher curing temperature $\left(300^{\circ} \mathrm{F}\right)$ to stabilize them. 


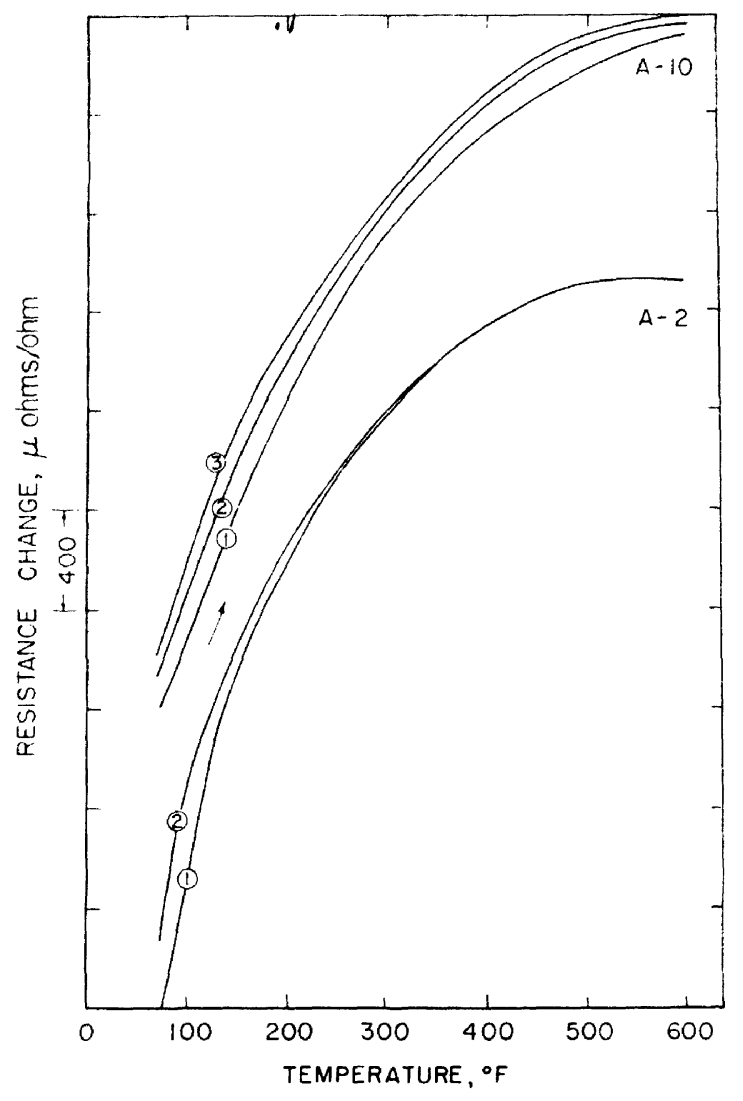

Figure 23. Heating curves at $15^{\circ} \mathrm{F} / \mathrm{min}$ for experimental cements $A-\mathcal{2}$ and $A-10$, preheated for $2 \mathrm{hr}$ at $130^{\circ} \mathrm{F}$. Numbers on curves indicate first, second and third beatings. (Cooling curves omitted.)

After being given the minimum preheating rerequired for stable operation to $600{ }^{\circ} \mathrm{F}$ three cement specimens were cycled from room temperature to $800^{\circ} \mathrm{F}$ at $150^{\circ} \mathrm{F} / \mathrm{min}$. None fell within the limits established for reproducibility. One of the potassium silicate cements caused a very large positive zero shift after the first cycle. Examination of the specimen revealed numerous cracks in the cement and some separation of the cement from the base. Apparently, the cement is dimensionally unstable for rapid cycling to $800^{\circ} \mathrm{F}$, after only a $130^{\circ} \mathrm{F}$ cure.

\section{b. Theory for Cement Instability}

It is postulated that one of the reasons for cement instability after a low-temperature preheating treatment is the volatilization of chemically held water (or other constituent) when the cement is subsequently heated to a higher temperature. The disturbance in the cement structure caused by the volatilization could increase momentarily the electrical conductivity, and thus tend to short circuit the strain gage. This hypothesis can best be explained by following the temperature cycle shown graphically in figure 24 . The cement in this case was a phosphate type, dried overnight in an atmosphere of 45 percent

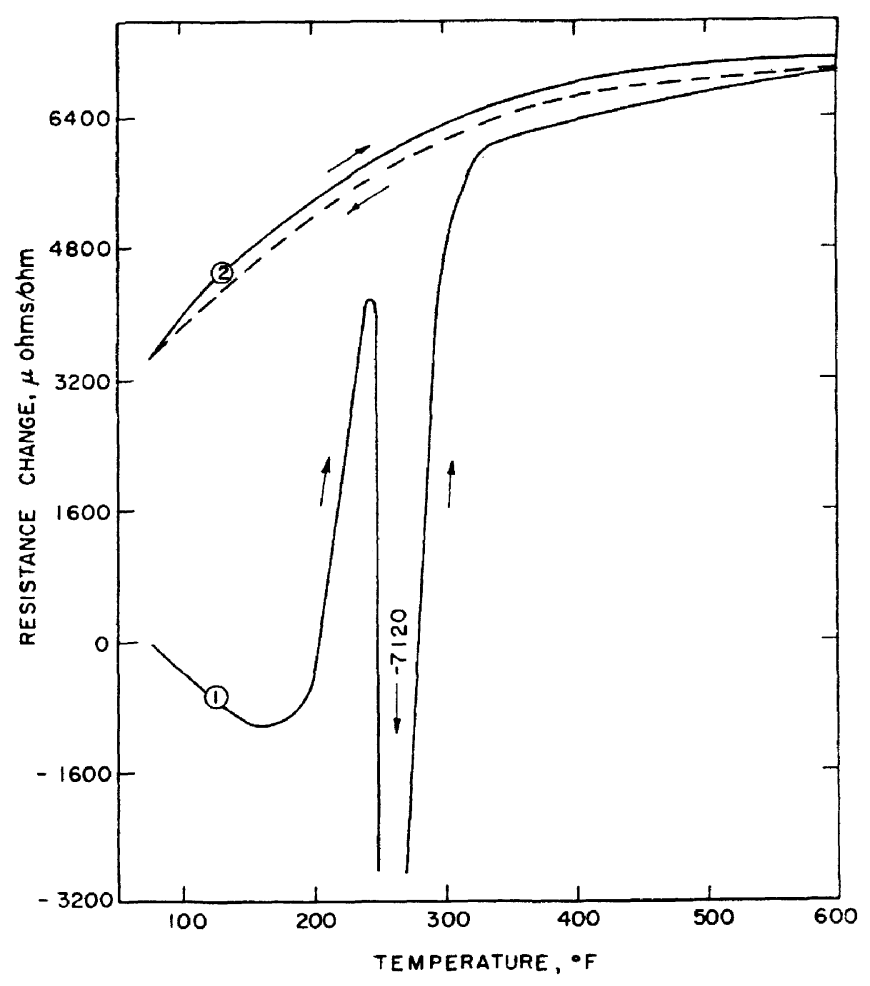

Figure 24. Heating and cooling curves at $15^{\circ} \mathrm{F} / \mathrm{min}$ for a phosphate-bonded cement $(C-10)$ after 16 hours air drying (no preheat treatment).

relative humidity, but given no preheat treatment. As the specimen begins to heat at $15^{\circ} \mathrm{F} / \mathrm{min}$, the adsorbed and/or absorbed moisture begins to vaporize, reducing the resistance of the cement and thereby reducing the apparent resistance of the wire. At about $175^{\circ} \mathrm{F}$ most of the moisture that is not structurally held has been driven off and the resistance of the cement begins to increase as the last traces leave the structure. This increase is reflected by a sharp rise in the apparent resistance of the wire. Next, at about $240^{\circ} \mathrm{F}$ the evolution of structural moisture begins and proceeds at a rapid rate, which is reflected by a large reduction in resistivity of the cement. The effect of this evolution of structurally held water reaches a maximum at about $265^{\circ} \mathrm{F}$. Finally at about 325 ${ }^{\circ} \mathrm{F}$ virtually all of the structurally held water has been evolved, and the cement has achieved a stable state. Further heating and cooling will cause no sharp changes in its conductance. The room temperature zero shift is probably due not only to the fact that the now thoroughly dry cement is more insulative than it was initially, but also to other causes such as structural drift of the wire, corrosion of the wire, and shrinkage of the cement.

Figure 25 shows the behavior of four different specimens of this same cement on the first heating to $600{ }^{\circ} \mathrm{F}$ after various preheat treatments. It can be seen that $16 \mathrm{hr}$ at $120^{\circ} \mathrm{F}$ produced sufficient drying to eliminate the initial lowering of resistance shown in figure 24 , but there remained a sharp decrease in resistance having maximum 


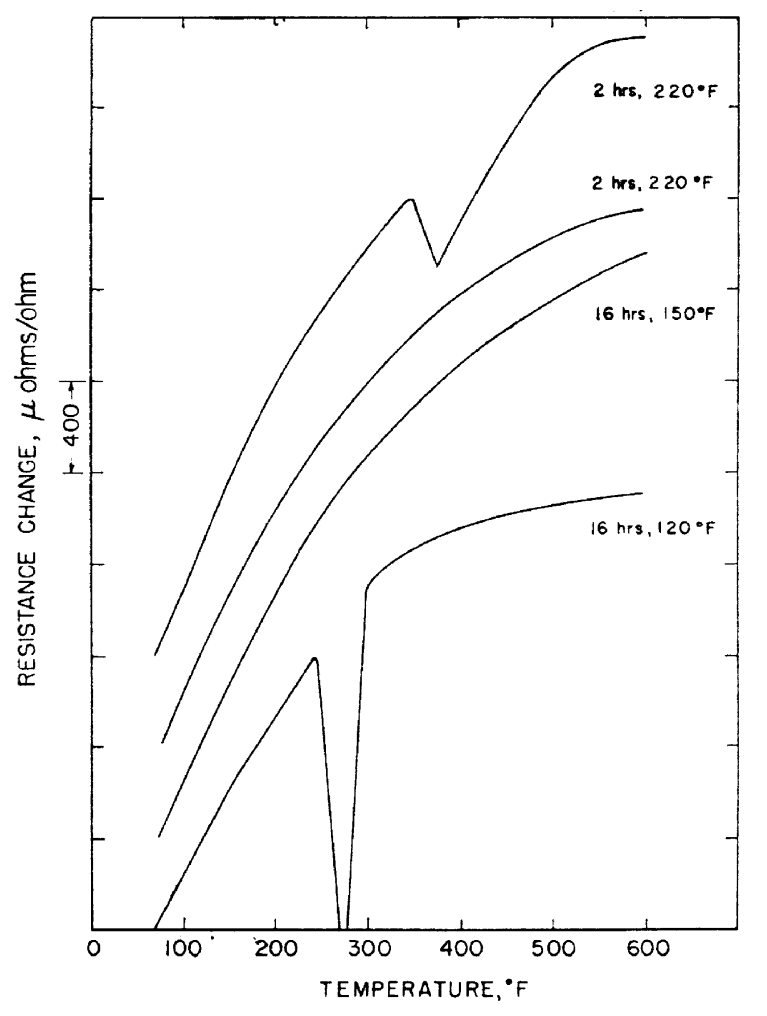

FiguRE 25. First heating curve for each of four specimens of a phosphate bonded cement $(C-10)$.

The temperature and duration of precuring treatment is shown for each curve. The three lower curves were obtained at a heating rate of $15{ }^{\circ} \mathrm{F} / \mathrm{min}$, the top curve at $150^{\circ} \mathrm{F} / \mathrm{min}$.

effect at about $265^{\circ} \mathrm{F}$. The zero shift (not shown) was also still excessive. Preheating for either 16 hr at $150{ }^{\circ} \mathrm{F}$ or $2 \mathrm{hr}$ at $220^{\circ} \mathrm{F}$ was sufficient to eliminate the erratic effect shown in the bottom curve. However, when the heating rate was increased from $15^{\circ} \mathrm{F} / \mathrm{min}$ to $150^{\circ} \mathrm{F} / \mathrm{min}$ (the top curve in fig. 25) an inflection occurred, beginning at about $350^{\circ} \mathrm{F}$. This behavior could mean that a minor amount of "curing" of the cement occurs during a test in which the heating rate is slow; on fast heating, however, the small amount of water remaining in the structure comes out suddenly, thereby disrupting the structure and lowering the resistance.

The belief that the lowered apparent resistance of the wire is caused by leakage through the cement was strengthened by two experiments. First, tests were made in which changes in apparent wire resistance and resistance to ground were measured simultaneously during the first heating of each of several cemented specimens. Figure 26 is typical of the results. The curves are for a cement which had been preheated for $2 \mathrm{hr}$ at 220 ${ }^{\circ} \mathrm{F}$. It will be noted that the inflections in both curves (resistance to ground and apparent resistance of the wire filament) occur at approximately the same temperature.

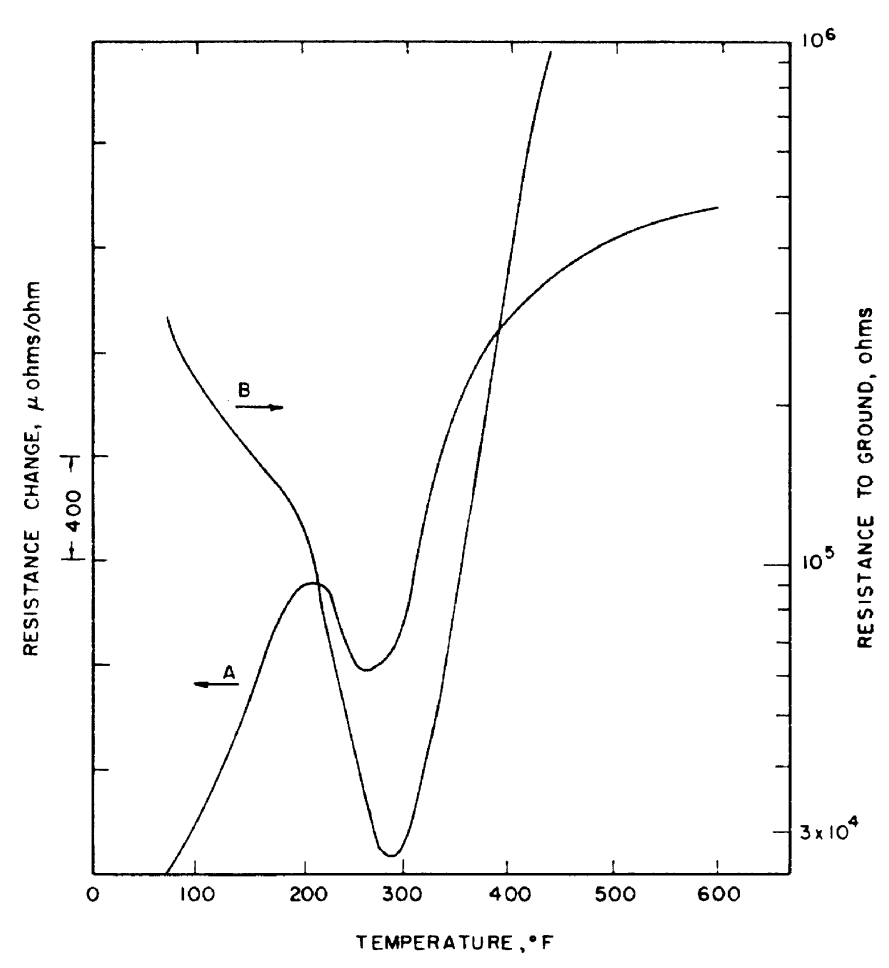

Figure 26. Apparent changes in wire resistance (curve $A$ ) and resistance to ground (curve $B$ ) during the first heating at $15^{\circ} \mathrm{F} / \mathrm{min}$ for a cement specimen $(C-12)$, that had been preheated for $2 \mathrm{hr}$ at $220^{\circ} \mathrm{F}$.

Despite the expected uncertainty in measuring the resistance to ground, the apparent change in measured resistance of the wire is in fair agreement with the change calculated by assuming that the resistance to ground is an electrical shunt in parallel with the gage. For example, at $75^{\circ} \mathrm{F}$ the apparent increase in wire resistance after heating to $600{ }^{\circ} \mathrm{F}$ was $320 \mu \mathrm{ohms} / \mathrm{ohm}$, whereas the increase calculated from the parallel resistances (bare wire: $70 \mathrm{ohms}$; cement, initial: 0.3 megohms; and cement, final: 10 megohms) is 230 $\mu$ ohms/ohm.

The second substantiating experiment involved coating of the gage wire and leads with an impervious porcelain enamel coating. At temperatures up to $600^{\circ} \mathrm{F}$, such a coating should provide adequate insulation for the gage, even though the resistance of the cement dropped to a very low value during the first heating. Figure 27 illustrates the effect of the precoating. The lower two curves show the resistance changes of an uncoated resistance wire that had been cemented with a phosphate cement, air-dried $16 \mathrm{hr}$, and then heated to $600^{\circ} \mathrm{F}$ at $15^{\circ} \mathrm{F} / \mathrm{min}$. The upper curves are the first three heating curves for a similar specimen except that in this case the gage (wire and leads) had been precoated with a 1-mil application of a porcelain enamel ground coat prior to cementing. The inflections present in the first curve for the 


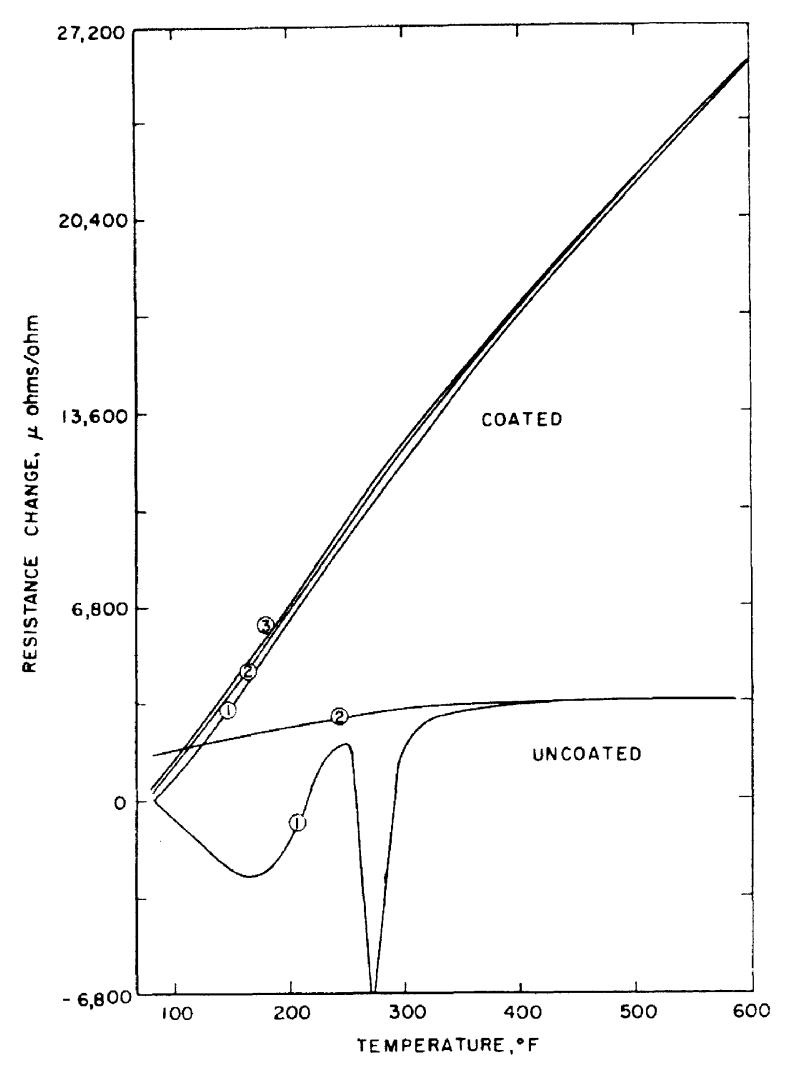

Figure 27. Resistance changes of coated and uncoated single-wire Karma gages that were attached to stainless steel with cement $C-10$ and cycled between room temperature and $600{ }^{\circ} \mathrm{F}$.

Cement was uncured (air dried only), but coated gage was protected with ceramic coating which was prefired on at $1,350^{\circ} \mathrm{F}$.

uncoated specimen did not occur for the coated specimen and in the latter case the change in resistance remained reasonably constant in successive cycles. 'This observation together with the measurements of resistance to ground, indicate quite strongly that much of the trouble from the erratic response of gages that have not been properly cured comes from electrical leakage in the cement.

A comparison of the slopes of curve 2 for both the coated and uncoated wire in figure 27 shows that the temperature coefficient of the Karma wire has been increased by a factor of about 14 by the firing treatment $\left(4 \mathrm{~min}\right.$ at $\left.1,350{ }^{\circ} \mathrm{F}\right)$ required for maturing the enamel ground coat. It is unfortunate from a practical standpoint that this firing treatment destroys the low-temperature coefficient of resistance of the Karma wire. However, it was found that precoating only the lead strips provided the necessary electrical insulation for gage stability, probably because the surface area of the wire is small compared with that of the leads. The Inconel leads were enamel coated, after which just enough of the coating was removed from the lead tips to permit spot welding of a strand of "as-received" Karma wire. This technique not only preserved the low-temperature coefficient of resistance of the Karma wire but also resulted in reproducible gage response for successive cycles to $600{ }^{\circ} \mathrm{F}$ at 15 - $\mathrm{F} / \mathrm{min}$ when the gage was attached with a potassium silicate cement and air dried only. It is not known whether or not this method would provide sufficient insulation where other cements or other gage types are used.

Two of the cements included in these tests contain silicone resins as the binder. These cements were found to have negative zero shifts after the first heating cycle, in contrast to the all-ceramic cements which displayed positive zero shifts. This could mean either the silicone cements were more conductive after the heat cycle or that shrinkage of the cement resulted in a compressive stress on the wire. To check the former, the resistance to ground was measured during a test of one of these cements which had been preheated for $2 \mathrm{hr}$ at $250^{\circ} \mathrm{F}$. The resistance to ground was initially greater than 10 megohms at room temperature, dropped to 2 megohms at $600{ }^{\circ} \mathrm{F}$, but returned to a value greater than 10 megohms at room temperature, thus ruling out leakage through the cement as the cause of negative zero shift. The stresses imposed on a wire by shrinkage of the cement can be quite complex, but in general they are compressive. If it is assumed that all of the stresses are compressive, then it follows that the axial stresses are the more effective, tending to shorten the wire and thus decrease its resistance rather than the radial stresses, which would reduce the cross-sectional area of the wire and increase its resistance.

\section{c. Relation of Minimum Curing Temperature to Oper- ation of Gages}

Mention was made earlier that the magnitude of the apparent strain errors indicated by these results is not necessarily the same as would be encountered in an acutal strain gage installation. If the error is due to leakage through the cement, the size and shape of the gage and the thickness of the cement precoat are important factors. For instance, in this work when the gage consisted of a 1-in. long $(70 \mathrm{ohm})$ strand of wire spot welded to ribbon leads, it was found that nearly all of the leakage was through the cement adjacent to the embedded portion of the leads. If it is assumed that the leakage from the leads remains constant, it can be shown that a higher resistance of the sensing element would result in a greater error; but, reduction in surface area of the leads would be expected to reduce the leakage. On the other hand, gages of the etched-foil type would probably show large errors because of leakage from the large surface area to the base and leakage between the many closely spaced legs of the gage. Of course, all types of gages would show greater leakage errors if the cement precoat thickness were reduced below the 3 mils used in this work. 


\section{Concluding Remarks}

The principal goal of the present investigation was to develop a resistance-type gage that would be suitable for measuring static strains up to $1,500{ }^{\circ} \mathrm{F}$. During the course of the program the various properties of possible gage materials were evaluated. In addition two new types of gages were developed and certain of their performance characteristics were determined. Also, a number of strain gage cements were evaluated, and finally a new cement was devised that showed superior electrical resistivity in the range 800 to $1,800{ }^{\circ} \mathrm{F}$.

Even with these contributions the present state of the technology of high-temperature strain gages leaves much to be desired. The major problems result from inadequate properties in available materials. The lack of a suitable alloy (or other conductor) for the strain-sensing element is one of the most serious obstacles. Karma and Evanohm, which are modified $80 \mathrm{Ni}-20 \mathrm{Cr}$ alloys (table 1), have provided a partial solution for intermediate temperatures, but above the 800 to $900{ }^{\circ} \mathrm{F}$ range, the performance characteristics of these and other alloys are severely limited. Evanohm and Karma are metastable, solid-solution alloys which have been given a special heat treatment so as to create a high electrical resistance and low-temperature coefficient of resistance; even so, their gage factors change with temperature and their drift rates increase with increasing temperature. Above about $900{ }^{\circ} \mathrm{F}$ most metals and alloys have such hightemperature coefficients of resistance that it is imperative to provide a means of correction; the gage may be temperature compensated or if its temperature is known precisely a suitable correction can be made. In addition to large temperature coefficients, many of the otherwise useable alloys undergo phase transformations on heating and cooling, and these changes usually have significant effects on the electrical resistance. These and some other problems associated with the selection of metals and alloys for high-temperature strain gages have been discussed by Graft [15] and Metcalfe [16].

The second major area in which additional improvement is needed is in the electrical insulation of cemented gages in the temperature region above about $1,000^{\circ} \mathrm{F}$. There are two approaches to the solution of this problem: One is to increase the electrical resistance of the bonding cement, and the other is to provide electrical insulation which is independent of the cement, as for example, by precoating the wire with a highly insulative material. The first method would be generally more desirable, inasmuch as the gage could be bonded and insulated in one operation. Cement $\mathrm{X}-142$ was developed to fill this need and, as indicated in table 2, in maintains comparatively high resistivity; up to 70 times that of any of those cements which also maintain any measurable bond strength. Yet, even a cement such as $\mathrm{X}-142$ may still not have sufficient resistivity for all types of measurement.

It is unlikely that cements chemically bonded to a metal substrate could have high-temperature resistivities comparable to the pure metal oxides such as $\mathrm{MgO}, \mathrm{Al}_{2} \mathrm{O}_{3}$, and $\mathrm{SiO}_{2}$. Many hightemperature cements contain such oxides as the filler material, but the bonding agents which are added to impart the "cementing" property have relatively low electrical resistivities. Furthermore, some ceramic cements react at high temperatures with metal surfaces (see fig. 4) and such reaction will result in large changes in resistance of the strain-sensing element during gage operation.

The technique of precoating a formed gage with an insulating ceramic is one solution to these problems. Both the protective quality of the coating on a fine wire heated in air and the insulative effect on a gage embedded in an incompletely cured cement were demonstrated in the present investigation. However, the high-temperature resistivity of the vitreous-type coating that was used was no better than that of the X-142 cement. Nevertheless, it is believed that with the aid of the electrophoretic coating technique as described in 3.4.b, ceramic coatings having superior insulative qualities can be developed. Such a coating might be composed almost entirely of pure oxide grains held together by a network of a vitreous or sintered phase.

Inasmuch as the total thickness of the layer between the gage elements and the substrate must be kept to a minimum, it is finally concluded that both the ceramic coating technique and the best insulative cement should be utilized to the maximum extent, if static strain measurements free of electrical leakage errors are to be achieved in the upper temperature regions.

\section{References}

[1] C. C. Perry and H. R. Lissner, The Strain gage primer, p. 253, (McGraw-Hill Book Co., New York, N.Y., 1955).
[2] Carl Schabtach and R. O. Fehr, Measurement of the damping of engineering materials during flexural vibrations at elevated temperatures, J. Appl. Mechanics, ASME Trans. 66, A86 (1944). 
[3] R. H. Kemp, W. C. Morgan, and S. S. Manson, The application of high-temperature strain gages to the measurement of vibratory stresses in gas turbine buckets, Nat. Advisory Comm. Aeronaut. Tech. Note 1174 (1947).

[4] F. G. Tatnall, Baldwin-Lima-Hamilton Corp., Philadelphia 42, Pa., unpublished summary report on high-temperature strain gage research, to Office of Naval Research, Washington 25, D.C., and Carbide \& Carbon Chemicals Co., Oak Ridge National Laboratory, Oak Ridge, Tenn. (Jan. 25, 1955).

[5] R. H. Kemp, W. C. Morgan, and S. S. Manson Advances in high-temperature strain gages and their application to the measurements of vibratory stresses in hollow turbine blades during engine operation, Proc. Soc. Exp. Stress Anal. [2] 8, 209 (1951).

[6] Anon., Properties of some metals and alloys, pp. 10-17, (International Nickel Co., New York, N.Y., 1951).

[7] R. H. Kemp, Advances in static and dynamic hightemperature strain gage research, Symposium on elevated temperature strain gages, Am. Soc. Testing Materials, Spec. Tech. Publ. No. 230, p. 23 (1958).

[8] D. G. Moore, Bonding agents for high-temperature strain gages, ibid, p. 106.

[9] J. R. Cuthill and W. N. Harrison, Effect of ceramic coatings on the creep rate of metallic single crystal and polycrystalline specimens, WADC Tech. Rept. $56-85$ (1956).

[10] D. G. Moore and J. R. Cuthill, Protection of lowstrategic alloys with a chromium-boron-nickel cermet coating, Am. Ceram. Soc. Bull. [11] 34, 375 (1955).
[11] T. R. Walters, Terratex-a thin flexible inorganic insulation, Trans. AIEE [1] 67, 123 (1948).

[12] Unpublished reports of the Engineering Mechanics Section, NBS.

[13] J. W. Pitts, E. Buzzard, and D. G. Moore, Resistance measurement of ceramic-type strain gage cements, Symposium on elevated-temperature strain gages, Am. Soc. Testing Materials, Spec. Tech. Publ. No. 230 , p. 67 (1958)

[14] A. Wexler and S. Hasegawa, Relative humiditytemperature relationships of some saturated salt solutions in the temperature range $0^{\circ}$ to $50^{\circ} \mathrm{C}$, J. Research NBS 53, 19 (1954) RP2512.

[15] W. H. Graft, Development of high-temperature strain gage wire, Symposium on elevated temperature strain gages, Am. Soc. Testing Materials, Spec. Tech. Publ. No. 230, p. 76 (1958).

[16] A. G. Metcalfe, The Stability of strain gage alloy wires, ibid, p. 109.

[17] E. W. Kammer and T. E. Pardue, Electrical resistance changes of fine wires during elastic and plastic strains, Proc. Soc. Exp. Stress Anal. [1] 8, p. 7 (1949).

[18] Metals Handbook, Am. Soc. Metals, Cleveland 3, Ohio, pp. 1062, 1122-24 (1948).

Washington, D.C., September 15, 1960 


\section{THE NATIONAL BUREAU OF STANDARDS}

The scope of activities of the National Bureau of Standards at its major laboratories in Washington, D.C., and Boulder, Colorado, is suggested in the following listing of the divisions and sections engaged in technical work. In general, each section carries out specialived research, development, and engineering in the field indicated by its title. A brief description of the activities, and of the resultant publications, appears on the inside of the front cover.

\section{WASHINGTON, D.C.}

Flectricity. Resistance and Reactance. Electrochemistry. Electrical Instruments. Magnetic Measurements. Dielectrics.

Metrolezy. Photometry and Colorimetry. Refractometry. Photographic Research. Length. Engineering Metrology. Mass and Scale. Volumetry and Densimetry.

Heat. Temperature Physics. Heat Measurement. Cryogenic Physics. Equation of State. Statistical Physics.

Radiation Physics. X-ray. Radioactivity. Radiation Theory. High Energy Radiation. Radiological Equipment. Nucleonic Instrumentation. Neutron Physics.

Analytical and Inorganic Chemistry. Pure Substances. Spectrochemistry. Solution Chemistry Analytical Chemistry. Inorganic Chemistry.

Mechanics. Sound. Pressure and Vacuum. Fluid Mechanics. Engineering Mechanics. Rheology. Combuation Controls.

Organic and Fibrous Materials. Rubber. Textiles. Paper. Leather. Testing and Specifications. Polymer Structure. Plastics. Dental Research.

Metallurgy. Thermal Metallurgy. Chemical Metallurgy. Mechanical Metallurgy. Corrosion. Metal Physics. Electrodeposition.

Mineral Products. Engineering Ceramics. Glass. Refractories. Enameled Metals. Crystal Growth. Constitution and Microstructure.

Building Technology. Structural Engineering. Fire Protection. Air Conditioning, Heating, and Refrigeration. Floor, Roof, and Wall Coverings. Codes and Safety Standards. Heat Transfer. Concreting Materials.

Applied Mathematics. Numerical Analysis Computation. Statistical Engineering. Mathematical Physics.

Data Processing Systems. SEAC Engineering Group. Components and Techniques. Digital Circuitry. Digital Systems. Analog Systems. Applications Engineering.

Atomic Physics. Spectroscopy. Radiometry. Solid State Physics. Electron Physics. Atomic Physics.

Instrumentation. Engineering Electronics. Electron Devices. Electronic Instrumentation. Mechanical Instruments. Basic Instrumentation.

Physical Chemistry. Thermochemistry. Surface Chemistry. Organic Chemistry. Molecular Spectroscopy. Molecular Kinetics. Mass Spectrometry. Molecular Structure and Radiation Chemistry.

- Office of Weights and Measures.

\section{BOULDER, COLORADO}

Cryogenic Engineering. Cryogenic Equipment. Cryogenic Processes. Properties of Materials. Gas Liquefaction.

Ionosphere Research and Propagation. Low Frequency and Very Low Frequency Research. Ionosphere Research. Prediction Services. Sun-Earth Relationships. Field Engineering. Radio Warning Services.

Radio Propagation Engineering. Data Reduction Instrumentation. Radio Noise. Tropospheric Measurements. Tropospheric Analysis. Propagation-Terrain Effects. Radio-Meteorology. Lower Atmosphere Physics.

Radio Standards. High-Frequency Electrical Standards. Radio Broadcast Service. Radio and Microwave Materials. Atomic Frequency and Time Interval Btandards. Electronic Calibration Center. Millimeter-Wave Research. Microwave Circuit Standards.

Radio Syetems. High Frequency and Very High Frequency Research. Modulation Research. Antenna Research. Navigation Systems. Space Telecommunications.

Upper Atmomphere and Space Phydes. Upper Atmosphere and Plasma Physics. Ionosphere and Exosphere Scatter. Airglow and Aurora. Ionospheric Radio Astronomy. 
